\section{History of the E.I. Martsinovsky Institute of Medical Parasitology and Tropical Medicine: research on malaria and leishmaniasis}

\section{História do Instituto E.I. Martsinovsky de Parasitologia Médica e Medicina Tropical: pesquisa sobre malária e leishmaniose}

Margarita V. Strelkova ${ }^{i}$

iResearcher, Martsinovsky Institute of Medical Parasitology, Tropical and Vector-born Diseases/Sechenov First Moscow State Medical University. Moscow - Russia

orcid.org/0000-0001-5705-9327 mstrelkova@mail.ru

\section{Alla M. Baranovaii}

i" Researcher, Martsinovsky Institute of Medical Parasitology, Tropical and Vector-born Diseases/Sechenov First Moscow State Medical University. Moscow - Russia

orcid.org/0000-0002-3767-9470

baralla@mail.ru

\section{Katrin Kuhlsii}

iii Researcher, Molecular Biotechnology and Functional Genomics/ Technical University of Applied Sciences.

Wildau - Brandenburg - Germany

Researcher, Research Platform Data Analysis and Simulation/Leibniz Centre for Agricultural Landscape Research. Müncheberg - Brandenburg - Germany

orcid.org/0000-0003-4168-8684

Katrin.Kuhls@zalf.de
STRELKOVA, Margarita V.; BARANOVA, Alla M.; KUHLS, Katrin. History of the E.I. Martsinovsky Institute of Medical Parasitology and Tropical Medicine: research on malaria and leishmaniasis. História, Ciências, Saúde - Manguinhos, Rio de Janeiro, v.27, n.4, out.-dez. 2020, p.1097-1124.

\section{Abstract}

This review presents the 100-year history of the Martsinovsky Institute of Medical Parasitology and Tropical Medicine in Moscow, Russia, starting with its foundation and early activities, and also describes the impact of its leading scientists, some of whom became internationally known. The institute headed a network of nine tropical institutes in the various Soviet republics from the 1920s to 1990 . The extensive body of literature on the history and research accomplishments of this institute has mainly been published in Russian; our goal here is to introduce these achievements and this expertise to the international scientific and medical community, focusing on malaria and leishmaniasis and the development of measures to control and monitor these diseases in the USSR.

Keywords: medical history; Russia; USSR; parasitology; tropical institute.

\section{Resumo}

O artigo analisa a história centenária do Instituto Martsinovsky de Parasitologia Médica e Medicina Tropical em Moscou, Rússia, desde sua fundação e primeiras atividades, e descreve a influência de seus principais cientistas, alguns dos quais viriam a conquistar renome internacional. $O$ instituto liderou uma rede de nove institutos tropicais em diversas repúblicas soviéticas entre as décadas de 1920 e 1990. A vasta literatura sobre o trabalho de história e pesquisa desse instituto foi publicada sobretudo em russo; nosso objetivo aqui é apresentar esse trabalho e conhecimento à comunidade médica e científica internacional, concentrando-se na malária e na leishmaniose e no avanço de medidas de controle e monitoramento dessas doenças na URSS.

Palavras-chave: história médica; Rússia; URRS; parasitologia; instituto tropical. 
$\mathrm{T}$ ropical medicine emerged as a specialized field in Europe during the era of colonial expansion. Russia had no colonies in the tropics, but did possess vast territories with hot climates. Even so, until 1920 the country had no specialized institutes to address diseases that thrive in hot conditions and few specialists (particularly in protozoology) with knowledge about the pathogens of humans and animal diseases from tropical countries (Yakimoff, 1915b). Meanwhile, the Western European colonial powers had established the first institutes of tropical medicine: the Liverpool School of Tropical Medicine in 1898, the London School of Tropical Medicine and Hygiene in 1899, the Hamburg Institute for Marine and Tropical Disease (now the Bernhardt-Nocht-Institut für Tropenmedizin) in 1900, the Institute for Colonial Medicine in Paris in 1902, the Lisbon School of Tropical Medicine in the same year, the Brussels School of Tropical Medicine (which moved to Antwerp in 1931 and today is the Institute of Tropical Medicine Antwerp) in 1906, the School for Health Services of the Colonial Troops in Marseille in 1907, and the Colonial Institute in Amsterdam (now the Royal Tropical Institute) in 1910. An inter-European network in tropical medicine also emerged, comprised of a qualified cadre, specialized journals, societies (such as the Société de Pathologie Exotique founded by A. Laveran and F. Mesnil in Paris, the Royal Society of Tropical Medicine and Hygiene, and the Deutsche Tropenmedizinische Gesellschaft, all founded in 1907), and scientific meetings and conferences (Neill, 2012). And in South America one of the most famous tropical institutes, the Federal Serotherapy Institute (now the Oswaldo Cruz Foundation) was founded in Rio de Janeiro in 1898, shortly after the establishment of the Brazilian Republic.

The E.I. Martsinovsky Institute of Medical Parasitology and Tropical Medicine was founded almost 100 years ago on August 30, 1920 in Moscow, and is one of the most important tropical institutes from a historical perspective, although unfortunately it has received far less attention in the international literature on medical history than institutions in Western Europe (see Figure 1). Some of the scientists who worked in this institute became well known far beyond Russia and made important contributions to the understanding of parasitic diseases such as malaria and leishmaniasis. One of the main roles of this institute was to coordinate and supervise measures to monitor and control parasitic diseases across the vast territory of the former Soviet Union (USSR) and to educate and train medical personnel working in these regions. To achieve this goal, nine additional tropical institutes were founded in the early twentieth century in the former Soviet republics, in Ukraine, the Southern Caucasus (Armenia, Azerbaijan, Georgia, Dagestan), and Central Asia (Uzbekistan, Tajikistan, Turkmenistan) (see Table 1 and Figure 2). 


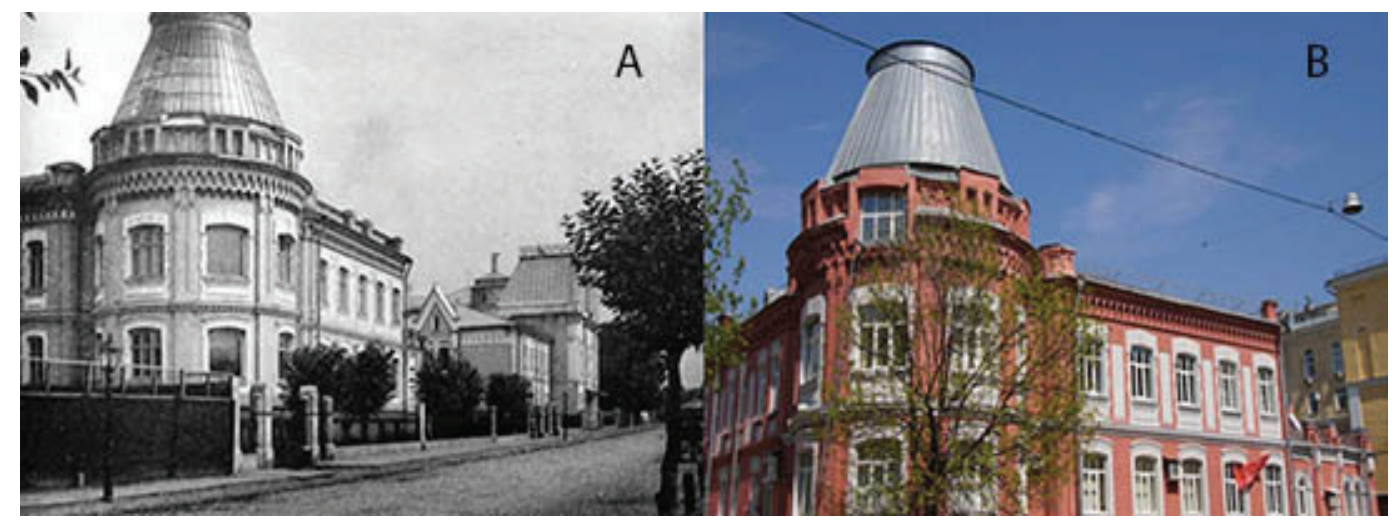

Figure 1: The Martsinovsky Institute of Medical Parasitology and Tropical Medicine in Moscow; (A) photo taken in 19001903, when it was a hospital for treatment of malignant tumors; (B) today (Archive of the Martsinovsky Institute, Moscow)

Table 1: Tropical institutes founded in the early twentieth century in the former Soviet republics

\begin{tabular}{|c|c|c|c|c|c|}
\hline Original name & $\begin{array}{l}\text { Former Soviet } \\
\text { republic }\end{array}$ & City & Founded & $\begin{array}{l}\text { Still } \\
\text { existing }\end{array}$ & Current name \\
\hline Tropical Institute & $\begin{array}{l}\text { Russian Soviet } \\
\text { Federal Socialist } \\
\text { Republic }\end{array}$ & Moscow & 1920 & Yes & $\begin{array}{l}\text { Martsinovsky Institute of Medical } \\
\text { Parasitology, Tropical and Vector-Borne } \\
\text { Diseases. Sechenov First Moscow State } \\
\text { Medical University. Ministry of Health. } \\
\text { Russian Federation }\end{array}$ \\
\hline $\begin{array}{l}\text { Institute of Malaria } \\
\text { and Medical } \\
\text { Parasitology }\end{array}$ & $\begin{array}{l}\text { Ukrainian Soviet } \\
\text { Socialist Republic }\end{array}$ & Kharkov & 1923 & No & - \\
\hline Tropical Institute & $\begin{array}{l}\text { Armenian Soviet } \\
\text { Socialist Republic }\end{array}$ & Yerevan & 1923 & Yes & $\begin{array}{l}\text { National Center for Disease Control and } \\
\text { Prevention. Ministry of Health. Republic } \\
\text { of Armenia }\end{array}$ \\
\hline Tropical Institute & $\begin{array}{l}\text { Georgian Soviet } \\
\text { Socialist Republic }\end{array}$ & Tbilisi & 1924 & Yes & $\begin{array}{l}\text { Research Institute of Medical Parasitology } \\
\text { and Tropical Medicine. Ministry of Health. } \\
\text { Georgia }\end{array}$ \\
\hline $\begin{array}{l}\text { Bukhara Tropical } \\
\text { Institute }\end{array}$ & $\begin{array}{l}\text { Uzbek Soviet } \\
\text { Socialist Republic }\end{array}$ & $\begin{array}{l}\text { Bukhara } \\
\text { Samarkand }\end{array}$ & 1924 & Yes & $\begin{array}{l}\text { Isaev Research Institute of Medical } \\
\text { Parasitology. Ministry of Health. Republic } \\
\text { of Uzbekistan }\end{array}$ \\
\hline Tropical Institute & $\begin{array}{l}\text { Dagestan } \\
\text { Autonomous } \\
\text { Socialist Republic }\end{array}$ & Makhachkala & 1927 & Yes & $\begin{array}{l}\text { Dagestan Research Institute of } \\
\text { Epidemiology, Microbiology, and } \\
\text { Parasitology. Ministry of Health. Republic } \\
\text { of Dagestan }\end{array}$ \\
\hline Tropical Institute & $\begin{array}{l}\text { Azerbaijan Soviet } \\
\text { Socialist Republic }\end{array}$ & Baku & 1931 & Yes & $\begin{array}{l}\text { National Research Institute of Medical } \\
\text { Prevention named after Akhundov. } \\
\text { Ministry of Health. Republic of Azerbaijan }\end{array}$ \\
\hline Tropical Institute & $\begin{array}{l}\text { Tajik Soviet } \\
\text { Socialist Republic }\end{array}$ & Dushanbe & 1931 & Yes & $\begin{array}{l}\text { Research Institute of Preventive Medicine. } \\
\text { Ministry of Health and Social Protection. } \\
\text { Republic of Tajikistan }\end{array}$ \\
\hline Tropical Institute & $\begin{array}{l}\text { Russian Soviet } \\
\text { Federal Socialist } \\
\text { Republic }\end{array}$ & $\begin{array}{l}\text { Rostov-on- } \\
\text { Don }\end{array}$ & 1934 & Yes & $\begin{array}{l}\text { Rostov Research Institute of Microbiology } \\
\text { and Parasitology. } \\
\text { Rospotrebsoyuz Russian Federation }\end{array}$ \\
\hline Tropical Institute & $\begin{array}{l}\text { Turkmen Soviet } \\
\text { Socialist Republic }\end{array}$ & Ashgabat & 1938 & No & - \\
\hline
\end{tabular}

Source: created by the authors. 


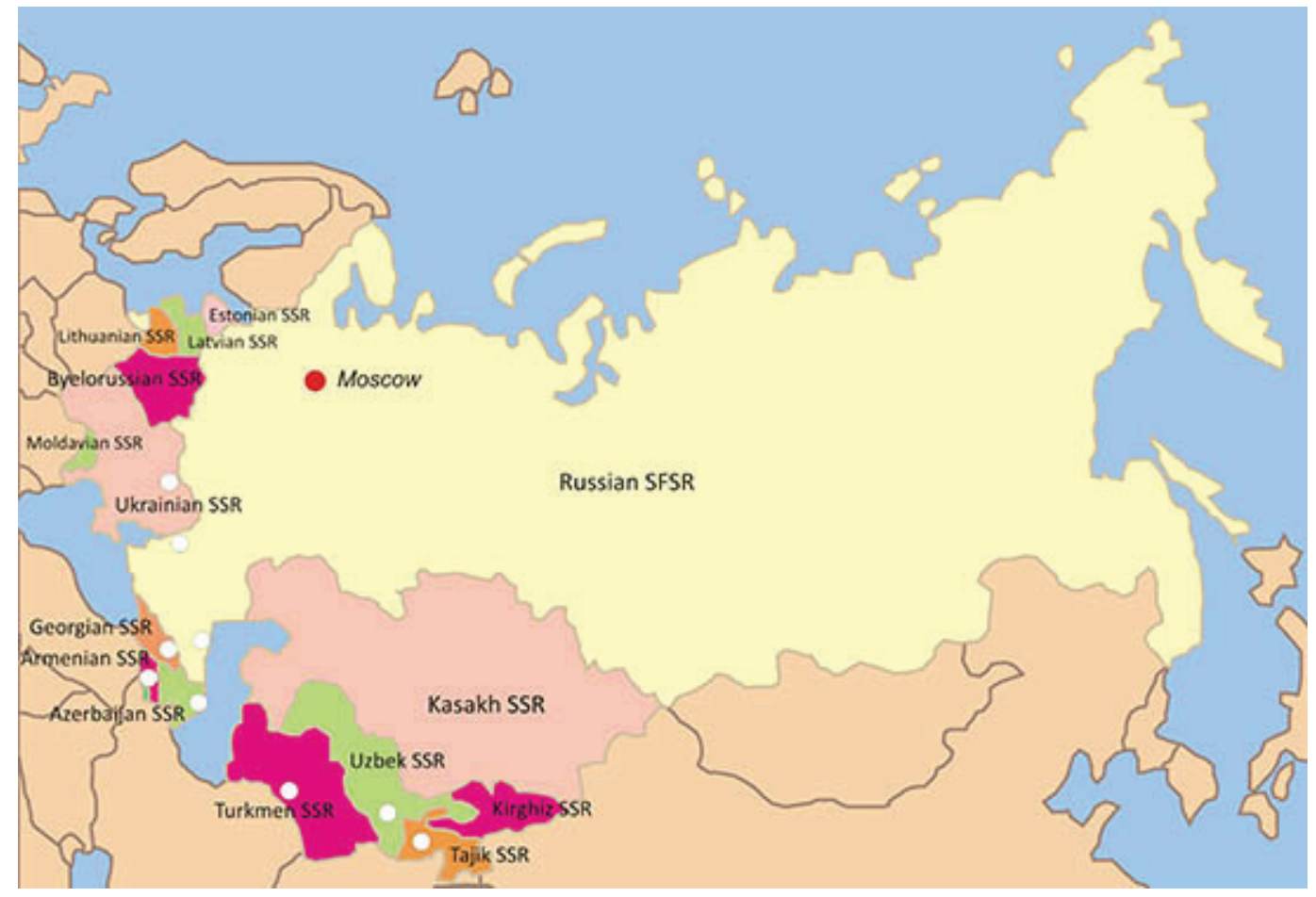

Figure 2: Map showing the location of the ten tropical institutes of the former Soviet Union. The Martsinovsky Institute is represented by a black dot (Map based on a vector graphic file from Fotolia with additional text, marks and colors added by the authors)

This article presents the history and expertise of the Martsinovsky Institute in the field of malaria and leishmaniasis research, since the extensive body of literature on this institute and its achievements in research, fieldwork, and disease surveillance and control for the most part is in Russian and not accessible to most experts and interested readers.

\section{Foundation, early history of the institute, and contributions by its founder}

\section{E.I. Martsinovsky and his early contribution to leishmaniasis research until the founding of the Tropical Institute}

The institute is named after its founder and first director, Evgeny Ivanovich Martsinovsky (Евгений Иванович Марциновский, 1874-1934) (see Figure 3). Martsinovsky was the son of a clerical worker in the city of Mstislavl, Russia (now Belarus). In 1899 he graduated from the medical branch of the Moscow State University. While at university, Martsinovsky became interested in bacteriology and worked for several years after graduation in the Department of Infectious Diseases at Pavlovsk Hospital, one of the oldest in Moscow (Martsinovsky, 1935). During this period, his attention was captured by parasitic protozoa; little was known about these organisms aside from their involvement in malaria, and because there were no specialists in protozoology he had no scientific peers to consult. Nevertheless, Martsinovsky discovered parasites located in cells from granulations of an 
ulcer in a patient from Persia. He sent the specimen to Charles Louis Alphonse Laveran (1845-1922) in France, one of the leading experts on protozoan parasites of that time and later a Nobel Prize laureate who worked at the Pasteur Institute in Paris, requesting an opinion. He received a quick response from Laveran and Félix Étienne Pierre Mesnil (1868-1938) in October 1903. In his letter, Laveran praised Martsinovsky for his research and for identifying the parasites described in 1903 by William Boog Leishman (18651926) and Charles Donovan (1863-1951) in patients infected with kala-azar (the visceral form of leishmaniasis) in India (Donovan 1903; Leishman 1903). Leishman suggested in 1903 that the observed parasites were degenerated forms of trypanosomes, while Laveran recognized them as a new parasite in the genus Piroplasma (Laveran, 1903). Ronald Ross (1857-1932), a British medical doctor from the Liverpool School of Tropical Medicine and 1902 Nobel Prize winner, finally determined that these ovoid bodies were parasites of a new genus, which in November 1903 he named Leishmania (Ross, 1903a). At the same time, Martsinovsky became familiar with the work of the American doctor James Homer Wright (1869-1928) from Massachusetts General Hospital in Boston, in which Wright described parasites from an ulcer in a girl who arrived in the US from Armenia (Wright, 1903). Soon Martsinovsky discovered earlier work by the Russian army doctor Peter Fokich Borovsky (Пётр Фокич Боровский, 1863-1932), who had worked in the Central Military Hospital in Tashkent since 1892. In 1898 Borovsky published a description in a Russian journal of similar parasites taken from the skin of patients who came to the hospital in Tashkent for treatment. He was the first to correctly recognize that the bodies in oriental sore lesions were protozoa, although he did not assign a name to the parasite in his publication (Borovsky, 1898). Unfortunately, this finding was unnoticed by international researchers for quite some time, until Cecil A. Hoare (1938) translated this article in 1938. Borovsky was cited indirectly by Laveran (1917) through the citation of Bettmann and Wasielwski (1909), and several times by Martsinovsky (1909,1912; Marzinowsky, Bogrow, 1904a, 194b), other Russian scientists (Yakimoff, 1915a, 1915b; Pawlowsky, 1927, 1931) and Petersen (1912). ${ }^{1}$ Despite publications by Leishman, Donovan, Laveran, Wright and Borovsky, there was no consensus about the nature of the pathogen that caused kala-azar until the end of 1904 or the one implicated in oriental sores until 1906. This included assignment within the kingdom (Bacteria, Fungi, Protozoa), but more importantly at the genus level (Sporozoa, Trypanosoma, Piroplasma, Myxosporidia, Leishmania etc.) (Cunningham, 1885; Borovsky, 1898; Leishman, 1903; Donovan, 1903; Laveran, 1903; Ross, 1903a, 1903b; Lühe, 1906; Bettmann, Wasielewski, 1909; Laveran, 1917; Gibson, 1983; Killick-Kendrick, 2010; Steverding, 2017). In December 1903, Wright named the parasite Helcosoma tropicum (Wright, 1903, 1904), while the following year Martsinovsky and Bogrov called the protozoan which caused oriental sore from the Caucasus Ovoplasma orientalis (Marzinowsky, Bogrow, 1904a; Marzinowsky, Bogrow, 1904b). Wright's second paper from January 1904, which corroborated Martsinovsky and Bogrov's observations, was published when Martsinovsky's paper was ready for press. Hoare emphasized in his paper that the conclusions made by Martsinovsky and Bogrov, although published almost one year after Wright's work, were completely independent of Wright. This was clear from correspondence between Mesnil, Laveran, Martsinovsky, and Wright, as well as Mesnil's 
1904 publication (Hoare, 1938; Mesnil, 1904). Martsinovsky and Bogrov examined the material described in their case between May and June 1903, while Wright examined his on July 28, 1903. The name assigned by Wright was changed in 1906 to Leishmania tropica by the German physician Max Lühe (1906). Meanwhile, eight years later two Russian doctors, Wassily Larionovich Yakimoff (Василий Ларионович Якимов, 1870-1940), who worked at that time in the Central Veterinary Laboratory in Petrograd (as St. Petersburg was known from 1914-1924), and Nathan Isaacovich Schokhor (Натан Исаакович Шохор, 1887-1941), suggested dividing $L$. tropica into the subspecies $L$. tropica var. minor and $L$. tropica var. major (Yakimoff, Schokhor, 1914). Based on the different types of lesions and appearance rural or urban regions, Bray et al. (1973) proposed classifying the respective parasites as the species L. major Yakimov and Schokhor, 1914, and L. tropica Wright, 1903.

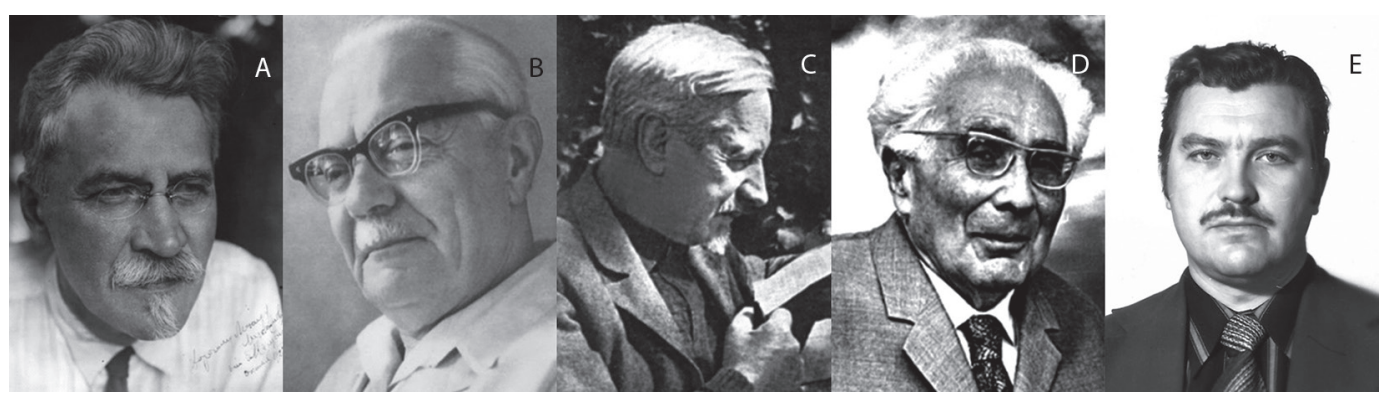

Figure 3: Leading scientists who worked at the Martsinovsky Institute of Medical Parasitology and Tropical Medicine: (A) Evgeny Ivanovich Martsinovsky (1874-1934), founder and first director from 1920 to 1934; (B) Peter Grigorievich Sergiev (1893-1973), director from 1934 to 1969, parasitologist, epidemiologist, doctor of Medical Science, professor, academician of the USSR Academy of Medical Sciences, honorary academician of the Hungarian Academy of Sciences, and WHO expert on malaria. He repeatedly presented reports at the assemblies and meetings of the WHO; (C) Vladimir Nikolayevich Beklemishev (1890-1962), zoologist, entomologist, founder of the USSR's school of medical entomologists, doctor of Biological Sciences, professor, full member of the USSR Academy of Medical Sciences and the Polish Academy of Sciences, foreign member of the Finish Society for the Study of Fauna and Flora, WHO expert on malaria; (D) Shabsay Davidovich Moshkowsky (1895-1982), epidemiologist, parasitologist, chemotherapist, doctor of Medical Science, professor, corresponding member of the USSR Academy of Medical Sciences, full member of the Polish Academy of Sciences, WHO expert on malaria, founder of the quantitative epidemiology of malaria; (E) Michael Mikhailovich Artemiev (1943-2002), entomologist, doctor of Biological Sciences, professor, specialist in the taxonomy of sandflies and mosquitoes. He made a significant contribution to the classification and taxonomy of sandflies of the Old World (Archive of the Martsinovsky Institute, Moscow)

In 1905 Martsinovsky headed an expedition to the Caucasus region to collect scientific materials from patients with leishmaniasis; at that time Russian researchers still knew little about leishmaniasis. To understand the etiology of oriental sore from the Caucasus region, Martsinovsky successfully infected himself in 1908 with parasites obtained from a patient, thus demonstrating that the causative agent in the Caucasus was the same as in other regions known up to that time. According to Bettmann and Wasielewski (1909), Martsinovsky's successful self-infection was among the most important and strongest evidence of transmission of oriental sore at that time. The detailed description of the parasite, illustrated by high-quality microscopic images of Leishmania on slides, as well as self-infection experiments and data from references available at that time formed the basis of the thesis The etiology of Oriental sore, which Martsinovsky (1909) wrote for the doctor 
of medicine degree he received in 1909 (see Figure 4). Martinovsky's publications from 1904 to 1912 on oriental sore, kala-azar, and canine leishmaniasis were frequently cited in Laveran's famous monograph, as well as by other medical specialists (Laveran, 1917; Marzinowsky, Bogrow, 1904b; Martsinovsky, 1909; Marzinowsky, 1909; Martsinovsky, 1912; Bettmann, Wasielewski, 1909), and consequently was recognized by experts of the era.

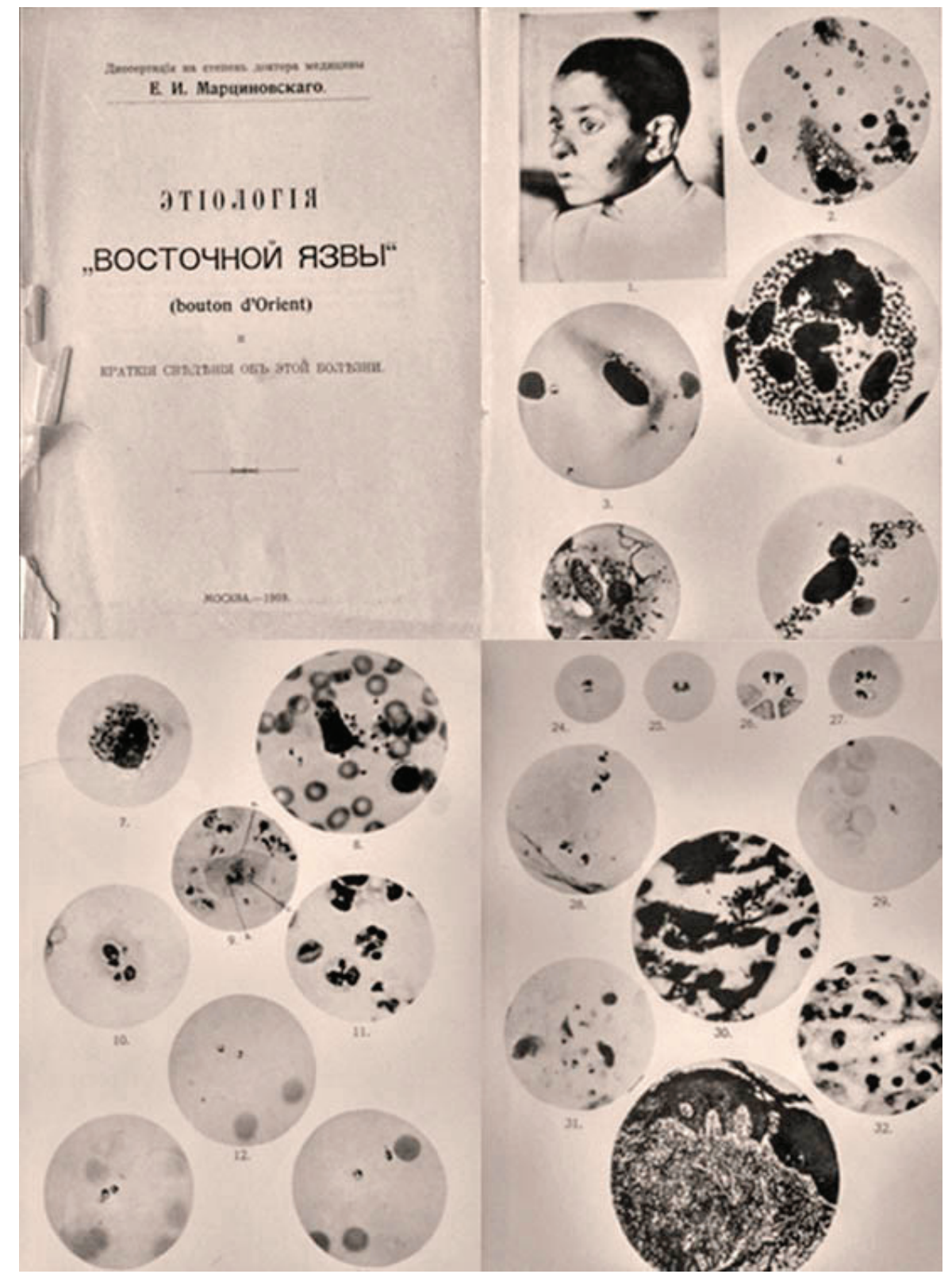

Figure 4: Front page of thesis entitled The etiology of Oriental sore by E.I. Martsinovsky in 1909 as part of his academic doctor of medicine degree. This text included microscopic images of leishmania parasites in the lesions of patients with cutaneous leishmaniasis from the Caucasus region (Archive of the Martsinovsky Institute) 
However, how the disease was transmitted remained unclear for quite some time, although the locally affected populations indicated that insects played a role (from Aleppo, as well as the Sarts in Turkestan, since the name of the disease, "peshe churdi," means "fly bite") (Russell, 1756; Tscherepnin, 1876; Marzinowsky, Bogrow, 1904b). The first indication that the disease was transmitted by a nocturnal hematophagous insect came in 1902 from Konstantin Yakovlevich Schulgin (Константин Яковлевич Шульгин), а Russian colleague of Borovsky working at the Tashkent hospital (Schulgin, 1902). But again, this publication remained internationally unnoticed until 1917, when Laveran included Schulgin's observations in his book on the leishmaniases (Laveran, 1917), although it was cited in 1904 in Martsinovsky's publication (Marzinowsky, Bogrow, 1904b). Martsinovsky also continued his studies on the transmission of the disease, and in 1917 he described the sandfly Phlebotomus (Paraphlebotomus) caucasicus Marz, 1917 (Martsinovsky, 1917). Edmont Sergent of the Pasteur Institute in Algiers suspected that Phlebotomus papatasi transmitted the parasites, based upon a publication by A. Prassat in 1905 about sandflies as possible vectors; Sergent and his brother Étienne Sergent confirmed this hypothesis in 1921 (Sergent et al., 1921). However, final proof of the role of sandflies came in 1941 from the Belarus-born British-Israeli parasitologist Saul Adler (1895-1966) (Adler, 1941), who at that time was working at Hebrew University in Jerusalem.

\section{E.I. Martsinovsky's contributions to malaria research and control efforts in the Russian Empire and during the first years of the USSR, and the foundation of the Tropical Institute in Moscow in 1920}

In the late nineteenth and early twentieth century, malaria was the most widespread infectious disease in imperial Russia. According to official statistics in 1902, 3.6 million patients were diagnosed (2,295 per 100,000) (Soprunov, Gold, 1986). That same year, a committee was established within the Society of Russian Doctors (Pirogov Medical Society) by Georgiy N. Gabrichevsky (chairman, 1902-1908), Nikolai M. Berestnev (chairman, 1908-1911), and E.I. Martsinovsky to study malaria in Russia and develop control measures. The committee's recommendations, however, were not implemented until 1911, when Martsinovsky became the chairman and successfully obtained financial support. He used these funds to organize expeditions to the most affected regions of Russia: the coastal regions of the Black Sea, the Caucasus region, and along the Volga River. The staff of the malaria committee presented lectures and published educational posters. In 1912, the first malaria station was founded at the initiative of this committee to control the disease in the Transcaucasian region in Batumi (now Georgia); the first educational courses on malaria control were held there. Many doctors from remote areas attended these courses, which were very important for future control of the disease. But anti-malaria activities ceased after the beginning of First World War in 1914 and the Revolution in 1917, followed by the Civil War in 1918-1920, and afterward the health care system collapsed almost entirely.

During the First World War at least 3.5 million people suffered from malaria each year in Russia, numbers stoked by huge population movements and a dysfunctional economy. In the 1920s Soviet Russia faced even bigger problems as malaria continued to expand throughout the country; famine again caused large-scale movements of the population. In 
19235.7 million patients were officially registered (4,246 per 100,000) (Soprunov, Gold, 1986), but the actual number of affected people was estimated at 12.5 million; that same year, 62,000 people died of malaria and 112 million workdays were lost (Soprunov, Gold, 1986). It was the largest malaria epidemic in modern times in Europe, and the disease spread even to the north of the country. Quinine was practically unavailable, and patients consequently could not be treated. Despite the extremely difficult economic situation and political instability in the country, the heavy burden placed on the country after four years of the First World War (1914-1918), three years of civil war (1918-1920), and several foreign interventions, a decision was made by the young Soviet government to establish the Tropical Institute in Moscow in 1920. Interestingly, 47 new higher educational institutions were founded during this difficult period, and the total number reached 138 in 1926, showing the Soviet government's emphasis on educating the population. Unlike several of the Western European tropical institutes, which had to partially rely on private-sector support based on the economic interests of private companies with colonial investments, this institute was fully financed by the government. Martsinovsky, as its first director, attracted many young, talented, and motivated researchers to work there. After his death in 1934, the institute was renamed the E.I. Martsinovsky Tropical Institute, and since 1959 it has been known as the E.I. Martsinovsky Institute of Medical Parasitology and Tropical Medicine.

The institute's main task was to determine how intensely malaria was spreading across the country, and to use this information and analysis of epidemiological situations to develop a systematic malaria control strategy to decrease the occurrence of this disease. In April 1921 a Central Malaria Commission was established at the People's Commissariat of Public Health (Narkomzdrav, founded in July 1918) of the Russian Soviet Federative Socialist Republic (RSFSR). Martsinovsky was a member of and active participant in the commission, and played an important role in organizing the control measures (Rashina, 1954). He introduced the idea of rural anti-malaria stations and also founded a powerful specialized network of such stations, and participated in training qualified personnel. Thanks to his organizing talent, between the founding of the USSR in 1922 and 1934 nine tropical institutes for the control of malaria and other parasitic diseases were created in Kharkov (Ukraine), Yerevan (Armenia), Tbilisi (Georgia), Bukhara (Uzbekistan), Makhachkala (Dagestan), Baku (Azerbaijan), Dushanbe (Tajikistan), Rostov-on-Don (Russian Federation), and Ashgabat (Turkmenistan), all functioning under the leadership of the Martsinovsky Institute (see Table 1, Figure 2). Significant funding was allotted for this ambitious purpose by the Soviet government, despite all the economic problems and foreign and domestic political challenges that faced the country at that time. The best researchers from the institute in Moscow were sent to these newly-founded institutes to take the lead and to create a qualified cadre in the young field of tropical medicine. About 2500 malaria stations were also established across the country. As a result, over a ten-year span an anti-malaria network of medical institutions was created in the USSR and staffed with qualified personnel (see Figure 5). An epidemiological department was established at the institute in 1930 and headed by Maria G. Rashina in order to scientifically and methodologically oversee the newly-created anti-malaria institutions. Additionally, in 1931 a structure for developing national anti-parasitic drugs (which 
was unique for the time) was established in the institute, and included laboratories to synthesize the drugs, conduct experimental chemotherapy and preclinical studies, and perform pharmacological assessments.

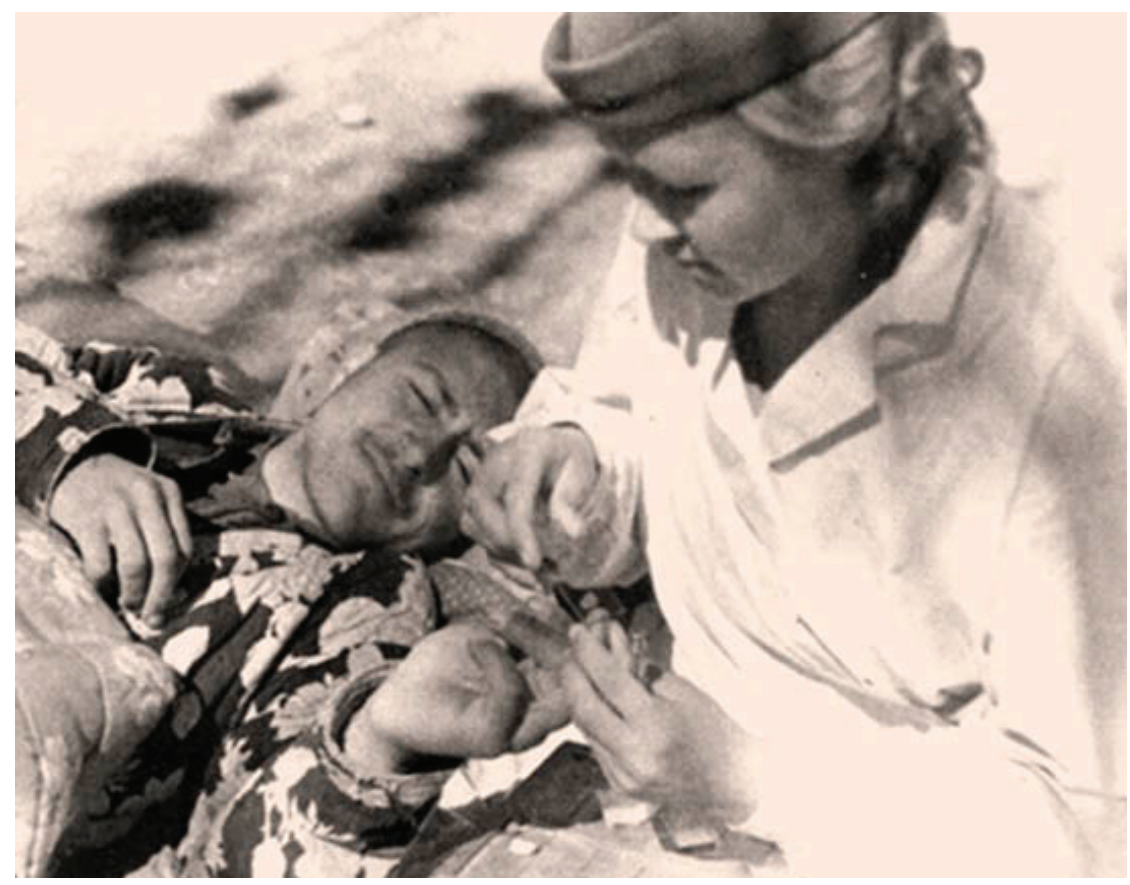

Figure 5: Taking blood samples from a patient with malaria in Uzbekistan, 1923 (Archive of the Martsinovsky Institut, Moscow)

At Martsinovsky's initiative, the Russian Journal of Tropical Medicine (Русский Журнал Тропической Медицины) was founded in 1923. It contributed significantly to the coalition of scientific forces within the country. In 1932, the journal's title was changed to Medical Parasitology and Parasitic Diseases (Медицинская паразитология и паразитарные болезни), and it continues to publish to this day. The journal has regularly published studies by medical parasitologists from all over the country, detailed information on congresses and conferences (which were frequent at that time), as well as decisions on main trends in medical parasitology.

Martsinovsky authored more than two hundred scientific publications in national and international journals, and was also a member of several Russian and foreign scientific organizations; for example, he was chairman of the League of Nations Health Organization's International Malaria Commission in 1934, the year when the USSR joined the League. A historical note about his role in organizing the campaigns against infectious diseases was presented by Sokolov (1959). After Martsinovsky's death in 1934, his disciple Peter Grigorievich Sergiev (Пётр Григорьевич Сергиев, 1893-1973) (see Figure 3) became the director of the institute, a post he held until 1969. Sergiev continued the legacy of his mentor and involved new employees as he continued to develop Martsinovsky's ideas on malaria control (Knopov, Taranukha, 2013). From 1934 onward he headed the State Program for Malaria Control, which in 1960 almost completely eliminated malaria in the USSR. 
Sergiev had brilliant organizational skills: he directed the institute while simultaneously heading the People's Commissariat of Health of the RSFSR (Minister of Health) (1937) and acting as head of its anti-epidemic board (1938). During Second World War he led the malaria department of the People's Commissariat of Health of the USSR. The institute's structure was extremely diversified prior to 1990. Various small but specialized and effective divisions with different profiles were gathered under one roof: epidemiology, entomology, protozoology, helminthology, pharmacology, chemotherapy, biochemistry, immunology, and synthesis of anti-parasitic preparations. The staff of many divisions spent 3-6 months each year on expeditions all over the country (see Figure 6).

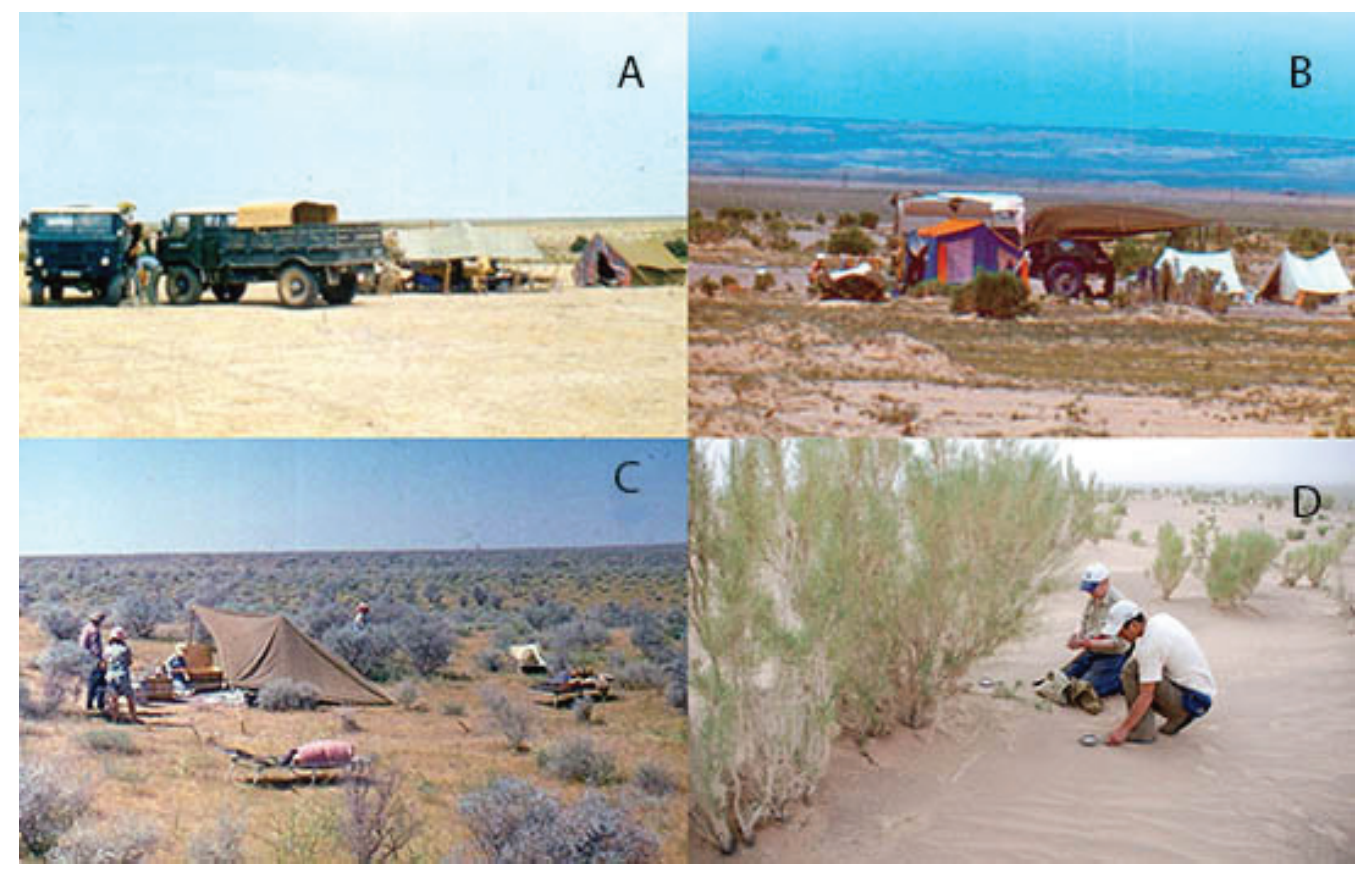

Figure 6: Field camps for expeditions to study the natural foci of zoonotic cutaneous leishmaniasis: (A) Uzbekistan; (B-D) Mongolia (Private archives of Margarita Strelkova, Anna Lushekina and Slava Popov)

The most important diseases targeted by the institute included malaria, leishmaniasis, amebiasis, giardiasis, leprosy, deep mycoses, tick-born encephalitis, phlebotomus fever, and different helminthiases (ancylostomiasis, opisthorchiasis, ascariasis, taeniasis, dracunculiasis, echinococcosis). This present article, however, is limited to two branches of this research, malaria and leishmaniasis, and lists only a portion of the numerous publications on these subjects.

\section{Malaria: research, control, and surveillance measures conducted by the institute}

Malaria control was one of the most important national objectives in the USSR and consequently for the staff of the Tropical Institute. In 1931-1932, together with the USSR State Planning Committee (Gosplan), the institute developed a scientifically-based plan to 
control malaria, which was approved and accepted for implementation by the government in 1934 after Sergiev's report (Resolution 1197 of the Council of People's Commissars of the USSR [Sovnarcom]) of May 20, 1934, "The All-Union action plan to control malaria." This was the first plan for malaria control at the state level in the history of medicine. Considerable funds were allocated between 1936 and 1940 to carry out the plan, which included constructing plants to producing medicine and insecticides and developing and manufacturing specific dusting equipment to apply insecticides. The institute became the center for scientific development of theoretical and practical solutions for malaria control, and specialists in parasitology, epidemiology, and entomology from the endemic regions of the country received training there. Malaria control measures in the USSR were conducted simultaneously in several directions: treatment and prophylactic actions as well as vector control were mainly performed by the malaria stations, while broad ameliorative and hydro-technical works were the responsibility of collectives and state farms created in 1929-1933 as the agricultural sector was collectivized.

During Second World War,, activities at the institute focused on research to prevent epidemics. Anti-malaria measures were developed and implemented, especially for the field army and regions with mass resettlement of evacuees. P.G. Sergiev also established the country's very first antibiotics laboratory at the institute, where a new antibiotic (Gramicidin S) that was urgently needed during wartime was developed in 1942 by Georgyi Frantsevich Gause and Maria G. Brazhnikova (Gause, Brazhnikova, 1944).

Despite these efforts, the incidence of malaria after Second World War, remained high: 3.36 million patients were diagnosed in 1946 (Baranova et al., 2003). During the postwar years, the public health services had to be reorganized after the devastation brought by the war between 1941 and 1945. Additional five-year plans for malaria control were developed by Sergiev and his colleagues and implemented by the government and the institute between 1946 and 1960; the country-wide anti-malaria program that was included in the five-year plan for 1951-1956 is an example. Because of large-scale use of insecticides such as DDT, GHTsG (hexachlorane) and therapeutic drugs that were synthesized in the USSR (such as Bigumal in 1947, Acriquine in 1933, and Plasmocid, an analog of Primaquin, in 1931), only 2,504 cases of malaria were diagnosed by 1958. In 1960, 368 patients were diagnosed and 57 carriers of the parasite were registered in 230 of the country's settlements (Baranova et al., 2003). After 1960 malaria was practically eliminated (Sergiev, 1955; Sergiev et al., 1961), with only local outbreaks occurring periodically in Azerbaijan and Tajikistan. These achievements and the commitment of the scientists involved were highly appreciated by the Soviet government and international medical community, and leading scientists as P.G. Sergiev, Vladimir N. Beklemishev, Maria G. Rashina, Nina K. Shipitsina, Evgeny M. Tareyev were honored with high-level government awards. In 1962 Tatyana S. Detinova received the prestigious international Laveran medal; P.G. Sergiev was granted the WHO's Darling award in 1966, and in 1978 his name was given to the mosquito Aedes sergievi by Danilov, Markovich and Proskuryakova (Danilov et al., 1978). The success of the USSR in malaria eradication was facilitated by the centralized and concerted healthcare policy of the country. A major focus in anti-malaria actions was curtailment of relapses and the 
occurrence of secondary cases, made possible by intensive surveillance and care of patients in a wide network of hospitals, polyclinics, anti-malaria stations, factory medical units, and healthcare units. It was based on early diagnosis, reliable notification, and detailed recordkeeping, as well as surveillance of former patients by visits to factories, collective farms, or schools. Another important characteristic of the Soviet malaria eradication strategy was the thorough planning of anti-malaria actions related to the socioeconomic development of the country, for example implementing new irrigation schemes, constructing hydroelectric power plants, clearing new areas (for agriculture, for example), and disseminating general public health education.

One of the most important aspects of malaria control was in-depth study of the vectors and designing methods to control them. Wide-ranging studies in biology, ecology, and mosquito systematics, along with assessment of their epidemiological significance, were conducted in different geographical zones across the entire USSR. The results of these studies are summarized in the book Ecology of a malaria mosquito, by Vladimir Nikolayevich Beklemishev (Владимир Николаевич Беклемишев, 1890-1962), which became a reference for entomologists and other specialists in malaria research (Beklemishev, 1944a) (see Figure $3)$. Beklemishev is one of the most famous Russian entomologists and founded the school of medical entomologists in the USSR, and is also acknowledged by the Encyclopedia of Entomology (Ioffe-Uspensky, Uspensky, 2008). His scientific publications include articles on the emergence of parasitism among arthropods, general principles of the organization of life, the spatial and functional structure of foci of infections through the example of malaria and tick encephalitis, and pathogens as members of the ecological community. One of his most important publications is the monograph Principles of comparative anatomy of invertebrates (Beklemishev, 1944b), which was translated in Romania and Poland in 1957, East Germany in 1958-1960, Great Britain in 1969, and the United States in 1970. Beklemishev was awarded high-level medals by the USSR, and his name was assigned to the mosquito Anopheles beklemishevi by Stegny and Kabanova in 1976 (Stegnii, Kabanova, 1976).

With the invention of long-lasting contact insecticides (DDT and GHTsG) in the late 1940s, mass destruction of flying mosquitoes in their natural habitats became possible. Special efforts were made to develop methods to eliminate mosquito larvae from different types of reservoirs. Various substances and application methods were tested; the most effective were recommended to the malaria stations for use in water treatment. In the 1950s, Valentina Petrovna Polovodova (Валентина Петровна Половодова) and Tatiana Sergeevna Detinova (Татьяна Сергеевна Детинова) developed a method to define the physiological age of mosquitoes (Detinova, 1962), which made it possible to assess the epidemiological danger of the vector's populations and efficiency of anti-mosquito measures and is still used in other countries. The study on vector phenology by Nina Konstantinovna Shipitsyna (Нина Константиновна Шипицына) was equally important to pinpoint the ideal timing for anti-mosquito treatment (Shipitsina, 1964).

Nadezhda Alexandrovna Tiburskaya (Надежда Александровна Тибурская) studied the malaria parasite, with continuous participation by Peter G. Sergiev. The causative agents of vivax malaria were classified according to the clinical course of disease, differentiating 
three types depending on the length of incubation and the probability, time until, and frequency of relapses (Soprunov, Gold, 1986; Garnham et al., 1975). They also showed that two types of Plasmodium vivax malaria could independently coexist in the human body, causing long and short incubation periods (Sergiev, Tiburskaya, 1963). This work was acknowledged by leading British parasitologists such as Percy Cyril Claude Garnham in a joint publication, as well as by Leonard J. Bruce-Chwatt, the Chief Medical Officer of the WHO's Malaria Eradication Division and former Director of the Ross Institute of Tropical Hygiene at the London School of Hygiene and Tropical Medicine (Bruce-Chwatt, 1959; Garnham et al., 1975).

In 1950, Shabsay Davidovich Moshkovsky (Шабсай Давидович Мошковский, 1895-1982) (see Figure 3) published a monograph entitled The main regularities of malaria epidemiology, in which he identified and performed quantitative analysis on a number of parameters to describe the epidemiological process in relation to malaria (Moshkovsky, 1950), establishing the foundation for modern mathematical modeling of epidemiological processes and a new direction in parasitology, quantitative epidemiology. Moshkovsky was one of Russia's most important and famous epidemiologists; at the eighth International Congress on Tropical Medicine and Malaria in Tehran in 1968 he presented a report entitled On new directions in epidemiology, which attracted the attention of many participants. Under his leadership, many studies were conducted on the properties of the pathogen under the influence of various drugs. For many years he maintained scientific and personal contact with his colleague Professor Wallace Peters (UK), a world authority in malaria research. Moshkovsky was awarded several orders and medals by the USSR and the Bulgarian order of Cyril and Methodius for significant contributions to scientific activity.

In subsequent years research on malaria was associated with the study of features of early and late recurrences, their relationship with the duration of the incubation period, and the origin of P. vivax strains (Beljaev, et al., 1986; Moshkovsky, 1973). The theory of polymorphic sporozoites was proposed to explain the phenomena of tertian malaria (Lysenko et al., 1977). For many years, the efficiency of therapeutic drugs including chloroquine was tested against different strains of $P$. vivax (Rabinovich et al., 2010). Other studies in the 1970s focused on drug resistance, and were also financially supported by the WHO. New substances were discovered, such as dabequin (dabechine), which after intensive preclinical trials was successfully tested in clinical trials on a larger scale in the USSR as well as Cuba and Vietnam. Furthermore, technology was developed to extract arteminisin from local wormwood, and the substance was fully tested in preclinical trials (Fedorova, Khomchenovskii, 1988a, 1988b).

\section{Leishmaniasis: research, control, and surveillance activities conducted by the institute}

Three forms of leishmaniasis were registered in Soviet territory: visceral leishmaniasis (VL) (Leishmania infantum), anthroponotic cutaneous leishmaniasis (ACL) (L. tropica), and zoonotic cutaneous leishmaniasis (ZCL) (L. major). Leishmaniasis is a threat in Armenia, Azerbaijan, Georgia, Kazakhstan, Kyrgyzstan, Tajikistan, Turkmenistan, Uzbekistan, and 
Crimea; the distribution of VL in the former Soviet republics has been described in detail by Strelkova et al. (2015). In the past, ACL was significant in cities in Transcaucasia and Central Asia, but after extensive control efforts this form was almost completely eliminated by the 1960s (Saf'janova, Aliev, 1973). During the second half of the twentieth century VL continued to be a problem, with natural foci where wild canids were reputedly a reservoir (Strelkova et al., 2015), and along with ZCL with its principal natural host Rhombomys opimus (the great gerbil). One of the institute's most important coordinative achievements was the almost complete elimination of ACL and of VL in urban areas where dogs were a reservoir.

Studies on leishmaniasis were continued by Martsinovsky in 1923-1924, when he was already the director of the Tropical Institute. He and Alexandra Ivanovna Shchurenkova (Александра Ивановна Щуренкова) conducted self-infection experiments, proving that immunity to CL only occurs when natural scarring is complete (Martsinovsky, 1935; Martsinovsky, Shurenkova, 1924). More extensive studies had begun by the late 1950s, and included research on vectors, pathogens, reservoirs, vaccination prophylaxis, and development of control methods. A distinctive feature of the institute's strategy was to combine fieldwork and experimental efforts. In long-term field research in Crimea, Azerbaijan, Kazakhstan, and Uzbekistan, Anna Vikulovna Dolmatova (Анна Викуловна Долматова ) and Tatiana Ivanovna Dergacheva (Татьяна Ивановна Дергачева) investigated sandfly fauna in these areas and their distribution in different biotopes (Dergacheva, 1969; Dolmatova, Demina, 1965), as well as the seasonal activity of specific species and their attacks on humans in natural habitat (Dergacheva et al., 1978; Dergacheva, Strelkova, 1985). Data on the biology and ecology of sandflies was expanded by Lev Nikolaevich Eliseev (Лев Николаевич Елисеев) and Margarita Vital'evna Strelkova (Маргарита Витальевна Стрелкова), who researched the ability of several sandfly species to transmit the causative agent under experimental conditions and assessed their food preferences (Eliseev, Strelkova, 1970; Strelkova et al., 1982; Strelkova, Eliseev, 1983).

Especially important was the research on sandflies conducted by Mikhail Mikhailovich Artemiev (Михаил Михайлович Артемьев, 1943-2002) (see Figure 3), an internationally known specialist in sandfly taxonomy. In his works he described tribes, subtribes, genera, species, and subspecies, discovered new species in the fauna of eight countries, and compiled an illustrated manual to identify the sandflies of the USSR, Afghanistan, Syria, and the Old World in general (Artemiev, 1978; Artemiev, Neronov, 1984) which is one of the most important taxonomic keys used worldwide. Many specialists in entomology from the Soviet Union and abroad consulted with him on the taxonomy of sandflies and mosquitoes. The taxonomic revision of the subgenus Adlerius, which includes the majority of VL vectors, resulted in better understanding of the fauna in many regions of the world and the interpretation of numerous but confusing data in prior reports (Artemiev, 1980).

During the first years of the Soviet Union, the country needed to synthesize its own drugs to treat patients with leishmaniasis because the USSR did not have the means to buy drugs abroad at that time. Solusurmine, a pentavalent antimonial therapeutic, was synthesized at the All-Union Research Institute of Chemistry and Pharmaceutics in 
1939 and used with good results to treat VL patients (Kornetov, 1942; Mirzoyan, 1958; Bardzhadze, 1979). No cases of drug resistance were recorded up to 1979, but solusurmine was not effective in treating ZCL resulting from L. major. Olga Ivanovna Kellina (Ольга Ивановна Келлина) tested almost twenty therapeutic drugs belonging to different drug groups, all synthesized in the USSR, on laboratory animals. Monomycin (an antibiotic in the aminoglycoside group, an analog of paramomycin) was determined to be the most effective (Kellina, 1963), and after clinical tests on patients with ZCL it became the most commonly used drug to treat this disease in the USSR. Monomycin was successfully used to treat patients with ZCL caused by L. major in Sudan during the outbreak of CL in 1987 in Khartoum and the surrounding area (unpublished data); this was the only case in which this medication was used abroad. The development and use of monomycin in the Soviet Union was acknowledged by Bray (1972).

Another research focus was the possibility of immunization against ZCL. The method of artificial active immunization using living cultured Leishmania parasites is based on the well-known fact that having cutaneous leishmaniasis grants stable and practically lifelong immunity. The immunological efficiency of the artificial vaccination was proven in self-infection experiments by Martsinovsky and Shurenkova (1924), and the influence of strain peculiarities in ZCL agents on vaccination efficiency was studied at the Martsinovsky Institute by O. Kellina. A comparative study on the virulence of strains of various origins and the development of methods to assess their suitability for vaccination were carried out alongside experimental models (golden hamsters, non-bred white mice, and BALB/c mice), with prophylactic vaccination of volunteers. These volunteers were research associates at the Martsinovsky and the Gamaleya Institutes, as well as geologists, archeologists, and construction workers who resided in Moscow and spent time working in endemic regions of the country (Kellina, 1965). This research found that only vaccination with highly virulent strains that induce a typical post-vaccination process provided full protection against infection by L. major (Kellina, 1965). Meanwhile, vaccination with partially or fully attenuated strains of L. major did not induce leishmanial lesions and did not protect from ZCL infection (Kellina, 1974), demonstrating that virulence is the main characteristic determining the prophylactic significance of a strain (Kellina, 1980). These results were corroborated by a mass prophylactic vaccination campaign organized in 1965-1967 for military personnel living in non-endemic parts of the country who were called to emergency service in Turkmenistan and Uzbekistan. During this period about 9,500 people were vaccinated with six selected strains of $L$. major. Immunization and epidemiological efficiency were high, approaching 100\% (Sergiev et al., 1970; Kellina, 1981). The technical instructions on preparing inoculative material developed in Moscow were later used in Uzbekistan and Turkmenistan. Large-scale vaccination trials using live promastigotes were carried out also in Israel, where the same results were obtained (Greenblatt, 1980) after early findings by Saul Adler at Hebrew University (Gavron, 1997). Vaccinations using virulent strains that caused typical vaccination processes provided complete protection: out of 81 people vaccinated, none contracted the disease (Gunders et al., 1972; Naggan et al., 1972). Leishmanization was also frequently 
applied in Iran (Khamesipour et al., 2005; Khamesipour et al., 2006; Modabber, 1995), but problems occurred in some cases due to the use of live parasites. These included the development of large, long-lasting skin lesions, parasite persistence, exacerbation of other skin diseases, use of immunosuppressive drugs in response to the spread of HIV, occasional immunosuppression in the course of other vaccinations, and not least of all ethical reasons, and this approach was consequently discontinued (Handman, 2001; Palatnik-de-Sousa, 2008).

Testing a large number of strains on laboratory animals showed that isolates from ZCL patients always caused ulceration and rapid progress of the disease. Meanwhile, isolates from great gerbils caused different reactions in laboratory animals, from rapidly developing ulcers to smoldering infiltrates. For a long time, this phenomenon was explained as intraspecies variability of virulence in $L$. major. But the introduction of biochemical and molecular methods in the 1980s at the institute and cloning of Leishmania strains proved that not one but three species of Leishmania circulated in a population of great gerbils; in morphological terms these species only differed slightly, and as a result had previously been recognized as a single species. Strelkova and colleagues from the London School of Hygiene and Tropical Medicine conducted a taxonomic revision of Leishmania circulating in great gerbils in 1985-1990, subdividing L. major into three species: L. major s. str., L. gerbilli, and L. turanica. The latter was described as a new parasite of $R$. opimus (Strelkova et al., 1990). Only L. major s. str. proved to be pathogenic to humans, while the other two were specific parasites of the great gerbil. Moreover, these species were shown to coexist in the skin lesions of a single animal. This study significantly changed previous understanding of the epidemiological and epizootiological aspects of ZCL in Central Asia (Strelkova, 1996; Strelkova et al., 2001).

Traditionally, development of evidence-based methods to combat parasitic diseases was of great relevance to the institute. A large-scale project involving development and irrigation of vast areas to grow cotton in Uzbekistan and Turkmenistan began in the 1960s, and large groups of people originally from non-endemic regions were involved in building canals, pumping stations, and new settlements. There was a real threat of ZCL outbreaks among people living close to natural sources of infection, namely the great gerbil. Eliseev's concept of protecting the population from ZCL in the Karshin steppe in Uzbekistan (Eliseev, 1980) was implemented by anti-leishmaniasis expedition staff (a specially-created division of the institute) in 1972-1989 during the first and second phases of development and irrigation. The scientific foundation of these control activities was to map all the great gerbil colonies using large-scale aerial photography, and began in 1968. This mapping was complemented with the locations of the irrigation system and human settlements. Extermination was undertaken within the areas isolated by the large canals and reservoirs that were constantly filled with water, which served as insurmountable obstacles for gerbils from neighboring territories (Eliseev, 1981). This approach permitted the efforts to focus only on eradicating the gerbils, avoiding sandfly treatments inside their burrows and in turn significantly reducing the cost of the project and expanding the infection-free area each year. Today, a large area where great gerbils were eradicated still remains free of ZCL. 


\section{International and national cooperation}

Throughout the nineteenth and early twentieth century, Russian scientists communicated and collaborated closely with colleagues from other countries, often working in foreign laboratories and conducting scientific and medical expeditions. For instance, during the early part of the twentieth century Evgeny I. Martsinovsky went on an expedition to Persia (today, Iran), and in 1911 he traveled to Italy to learn how to organize anti-malarial activities that had been introduced there. From 1900 to 1905, Vassily L. Yakimov and his wife Nina K. Kohl-Yakimova worked at the Pasteur Institute in Tunis, Tunisia. Later, Yakimov worked as an assistant at the Georg-Speyer-Haus in Frankfurt am Main (Germany), which was directed by Paul Ehrlich. During the first 20 years of the twentieth century, many Russian doctors and scientists published their studies in the leading medical journals of Russia as well as Western Europe, such as the Bulletin de la Société de Pathologie Exotique, Zeitschrift für Hygiene und Infektionskrankheiten, and Virchows Archiv für Pathologische Anatomie und Physiologie und für Klinische Medizin (in English, German, or French), but unfortunately this changed after 1920.

During the 1920s and 1930s, after the USSR was internationally recognized by Great Britain, France, Italy, and several other countries in 1924 and then the United States in 1933, followed by its entrance into the League of Nations in $1934,{ }^{2}$ the USSR maintained certain diplomatic, trade and cultural relations with a number of countries. Nevertheless, its scientists suffered from foreign policy isolation. Personal contact was hampered, mainly by economic, bureaucratic, and political obstacles constructed by the USSR and also distrustful attitudes among many Western countries towards the Soviet Union and its specialists thirty to forty years after the institute's founding; only a few Soviet scientists went abroad during this period. For many years, Soviet scientists only had indirect knowledge of foreign scientists and their research through articles and reports published in scientific journals that were widely available in Soviet libraries. This situation changed soon after Second World War in general, including for the specialists at the Martsinovsky Institute after their successful experience eradicating malaria in the USSR.

By the time the WHO Global Malaria Eradication Program began in 1955, with the involvement of fifty countries, the USSR had already accumulated significant experience in controlling this disease and had greatly reduced its occurrence within its borders. As a result, the WHO and international community could no longer ignore the USSR's antimalarial capability and the qualifications and accumulated knowledge and experience held by its specialists (Litvinov, 2010). P.C.C. Garnham of the London School of Hygiene and Tropical Medicine significantly helped involve Soviet malariologists in the work of international organizations as an organizer of international meetings from 1959 to the 1970s. Since 1959, the Soviet malariologists P.G. Sergiev, Sh.D. Moshkovsky, V.N. Beklemishev, Natalia N. Dukhanina, and Andrey Ya. Lysenko had been actively involved in the work of the WHO Expert Committee on Malaria and its Scientific Working Groups (Kuznetsov, 1990) and participated in numerous international conferences and congresses (e.g. International Congress on Tropical Medicine and Malaria). They shared their experience controlling malaria in the USSR and also pointed out the methodological and 
organizational shortcomings of their WHO colleagues. The USSR's experience and success in malaria control and eradication was strongly acknowledged by the parasitologist L.J. Bruce-Chwatt (1959), who wrote: “These achievements are of particular interest because the general strategy of malaria eradication in the USSR has many technical, administrative, and economic and social features not seen elsewhere". His text also contains an excellent compilation of publications by Russian and Soviet malariologists from 1890 to 1959. Their experience with malaria control in the USSR led them to define the main drawbacks of the approach used by their WHO colleagues as the unified approach to eliminating malaria in all different countries with the disease without considering their different levels of socioeconomic development or the quality of their public health systems, their different epidemiological situations, and differences in vector species composition and ecology. In these scientists' opinion, their WHO colleagues also underestimated the importance of scientific research during the preparatory phase and focused only on mosquito control without treating patients as a source of infection for mosquitoes, which was obviously necessary (Sergiev, 1955; Sergiev et al., 2007). The contact insecticide DDT was highly effective in controlling the mosquitoes that carried malaria; its use led to a sharp decline in the incidence of malaria, but constant and widespread applications of this substance for medical and agricultural purposes led to DDT resistance in mosquitoes (Bagirov et al., 1973; Berg, 2009). The USSR banned DDT production in 1969-1970, but accumulated stocks of the product continued to be used until the late 1980s. The interplay of these shortcomings, along with the ban on DDT, were why the WHO Malaria Eradication Program was not successful in all the countries it addressed.

Many of the staff at Soviet (and later, Russian) institutes worked in the WHO's regional offices and as WHO consultants and experts on malaria, and also visited various countries. Successful cooperation with the WHO also took place through the UNDP-World BankWHO Special Program for Research and Training in Tropical Diseases (TDR) after the founding of the WHO in 1975. Vladimir P. Sergiev and Olga I. Kellina served as members of its Expert Committee on Leishmaniasis, and staff at the Martsinovsky Institute organized and ran international courses, seminars, and training in field methodology for malaria and the leishmaniases which was arranged by the WHO and Soviet Ministry of Health and held in the USSR. In 1967 and 1980, scientists from leishmaniasis-endemic countries participated in training courses and field seminars on these diseases, which were also held in the USSR. The following well-known foreign scientists served as WHO consultants in these seminars: Oskar Theodor, David J. Lewis, and Philip Edmund Clinton MansonBahr in 1967, and Robert Killick-Kendrick, Cornelis J. Marinkelle, Richard W. Ashford, Arnon E. Gunders, and Hedva Pener in 1980 (WHO, 1980). The Martsinovsky Institute received Asian and African medical doctors who obtained further training by working in the different laboratories there. Scientists from the Martsinovsky Institute also traveled to and worked at various foreign research centers on scholarships to train in new methods and techniques and conduct joint research. The most successful collaborative project on the leishmaniases was done with staff at the London School of Hygiene and Tropical Medicine, which led to the identification of a new species of Leishmania (Strelkova et al., 1990). Collaborative centers were established together with the WHO: one on vector- 
borne diseases was started in 1981, another on tertian malaria in 1982, and a third on leishmaniases in 1986 (Litvinov, 2010; Baranova, 2010). The leishmaniases center brought together experts from the Martsinovsky Institute and Gamaleya Institute of Epidemiology and Microbiology, both of which are based in Moscow, as well as the Isaev Institute of Medical Parasitology in Samarkand, Uzbekistan.

During the late period of the USSR's existence, scientific cooperation within the framework of the Council for Mutual Economic Assistance (CMEA) alongside the socialist countries (the German Democratic Republic, Cuba, Czechoslovakia, Hungary, Poland, and Vietnam) and their research institutes covered research on epidemiology, diagnosis, and the prevention and treatment of tropical diseases (Litvinov, 2010). Specifically in Cuba, Vietnam, and Afghanistan (for control of dengue in the former and malaria in the latter two), this cooperation was very successful. Experts from the institute offered scientific and practical support on different aspects of tropical medicine to more than forty countries in Africa, Asia, and Europe, as well as Cuba. The Board of Directors of the European Schools of Tropical Medicine came from 14 countries: Austria, Belgium, Hungary, Spain, Netherlands, Norway, Poland, Portugal, Romania, the USSR, France, the Federal Republic of Germany (FRG), Czechoslovakia, and Switzerland. The directors of the Martsinovsky Institute participated in the Council's deliberations, decision-making process, and actions and in turn contributed to the exchange of information, interaction between specialists, and coordination of joint activities and projects on various aspects of tropical medicine (Soprunov, 1981; Litvinov, 2010).

Throughout the USSR's existence, the Martsinovsky Institute maintained close relationships with all the country's other institutes of medical parasitology with regard to teaching and training students at the higher postgraduate level (namely Ph.D. and D.Sc. degrees and postdoctoral projects). Numerous and regular conferences and congresses on various aspects of parasitology took place in the different republics. They brought together scientists, medical personnel, technical staff, and field workers from all of the Soviet republics to consider and evaluate the most important parasitological problems and decide on possible solutions. Cooperation was ongoing between scientists from the Martsinovsky Institute and those at other institutes in Moscow and Leningrad (now St. Petersburg) on parasitology and the problems caused by parasitic organisms. These scientists involved were Vera M. Saf'janova (Gamaleya Institute, Moscow), Peter P. Perfil'iev (Institute of Zoology, St. Petersburg), Andrey Ya. Lysenko, Andrey E. Beljaev (The Central Institute for Advanced Medical Training, Moscow), Valeriya D. Kallinikova and Alexander A. Kolesnikov (Lomonosov Moscow State University), Alexander F. Nikitin, Alexey I. Solovyov, and Sergey S. Kozlov (Kirov Military Medical Academy, St. Petersburg) (Saf'janova, 1986; Saf'janova, 1991; Saf'janova, Aliev, 1973; Perfil'ev, 1966; Lysenko, Beljaev, 1987; Saf'janova, 1982).

\section{Final considerations}

The Martsinovsky Institute will reach 100 years of scientific research in 2020. During this century, the staff of the institute addressed several of the country's priorities. Several 
generations of researchers have worked in the institute; some specialists, both retired and still active, are well known in the research community in Russia as well as abroad. The efforts of others were less recognized, but no less important. These years of daily efforts in laboratories, quite often under severe conditions (see Figure 6), yielded knowledge, solutions to old problems, and implementation of new programs to control parasitic diseases. Significant time was devoted to educating students at medical universities and specialists working in the sanitary and epidemiological service. The institute's main achievement was control and surveillance of all parasitic diseases in the huge country, including the Transcaucasian and Central Asian regions, from the 1920s until the dissolution of the USSR in 1991.

After the dissolution of the Soviet Union, considerable territories where malaria and leishmaniasis are endemic remain beyond the borders of Russia; today these diseases are usually brought in from other countries (Ponirovsky et al., 2015). Seven of the tropical institutes located in other former Soviet republics are still in operation (see Table 1). Most of them experienced serious financial and structural problems during the first years of independence, but they are now successfully continuing their work.

From 1992 to 2000 the institute suffered from the sharp reduction in financial support. On January 1, 2000, the institute was incorporated into the I.I. Sechenov Moscow Medical Academy, and in 2018 it was renamed the Martsinovsky Institute of Medical Parasitology, Tropical and Vector-Born Diseases, Sechenov First Moscow State Medical University. Since 2001 a number of structural improvements and renovations have been undertaken, including a specialized polyclinic for medical parasitology and tropical medicine, a new diagnostic laboratory for parasitic diseases, and the Department of Tropical Medicine and Parasitic Diseases for medical students and postgraduate training for specialists from the sanitary epidemiological service as well as for doctors at medical and preventive institutions.

Currently, the institute's main function is to provide training in medical parasitology, including courses for specialists from developing countries (see Figure 7). It holds the status of a WHO center for preparing a medical cadre in tropical medicine. The institute offers various postgraduate studies (Ph.D. studies, clinical residency), and a doctoral committee evaluates dissertations in parasitology and entomology. It also includes the Center for Diagnosis of Parasitic Diseases, where classical and molecular diagnostic methods are applied. International cooperation continues within the framework of research projects on malaria and leishmaniasis financed by national and international grants such as the Russian Fund for Basic Research (RFBR), WHO, TUBITAK (Turkey), the German Federal Ministry of Education and Research (BMBF), and the International Association of the EC (INTAS), and has yielded results which appeared in several publications (Strelkova et al., 2001, 2003, 2004, 2015; Elfari et al., 2005; Al-Jawabreh et al., 2008; Alam et al., 2009; Kovalenko et al., 2011; Sukiasyan et al., 2019). 


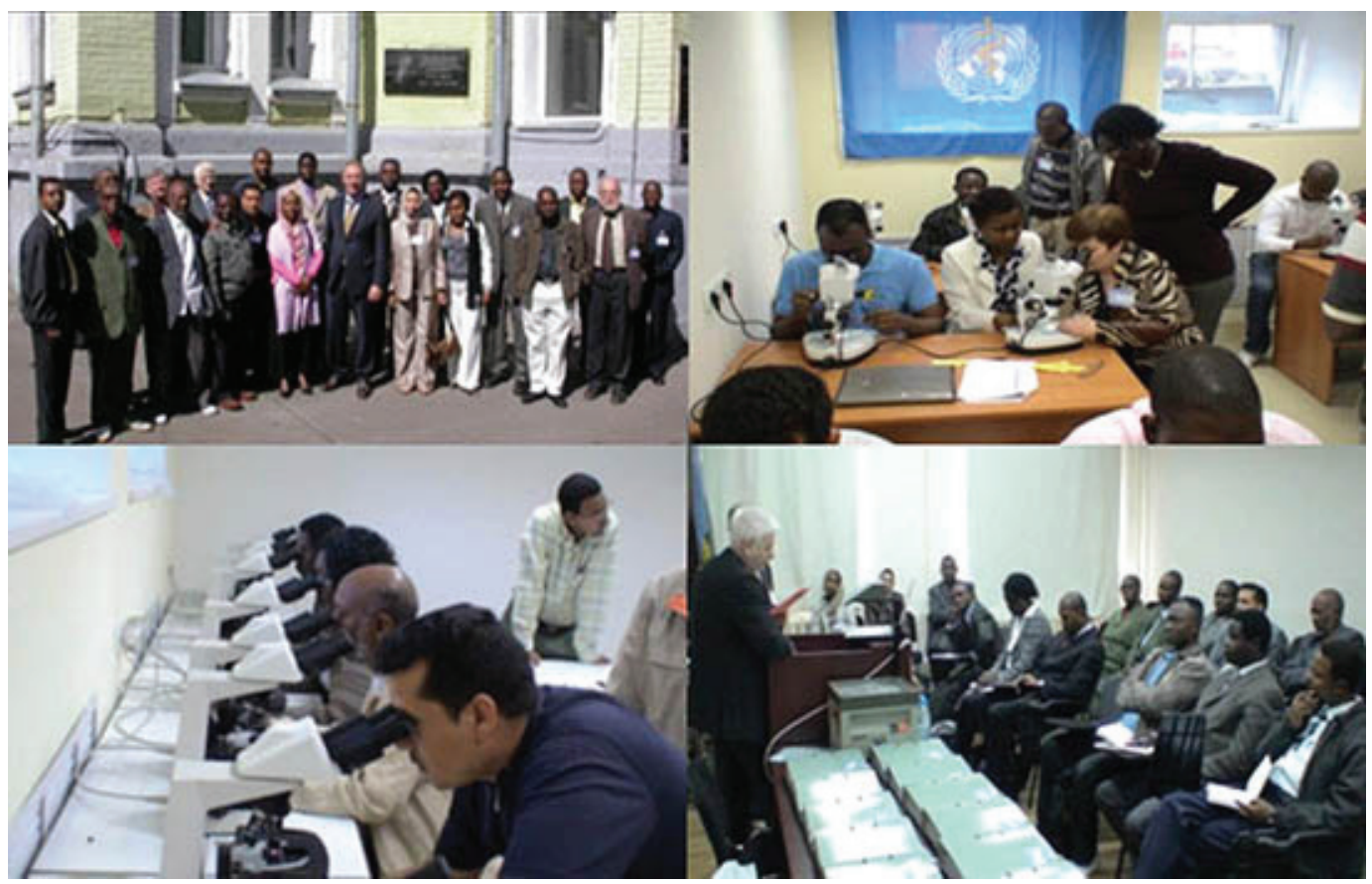

Figure 7: International workshop on malaria, conducted by the WHO at the Martsinovsky Institute (Archive of the Martsinovsky Institute)

\section{ACKNOWLEDGMENTS}

This study was supported by a grant by the German Federal Ministry of Education and Research (BMBF) (FKZ 01DK14021 Central Asia - Southern Caucasus Leishmaniasis Project). We would like to thank Sofia Cortes (Instituto de Higiene e Medicina Tropical/Universidade Nova de Lisboa, Portugal), Lee Schnur (The Hebrew University/Hadassah Medical School, Jerusalem, Israel), and Dan Bednarz (Massachusetts, USA) for critical reading and helpful comments on the manuscript. We also wish to acknowledge help from Sophia and Pola Aksenoff in translating an early version of this manuscript. The authors declare no conflicts of interest.

\section{NOTES}

${ }^{1}$ Due to differences in the transliteration of the Cyrillic alphabet to the Latin alphabet, the name of some authors presents slight differences in the way of writing. It is, however, the same person. For example: Bogrow/Bogrov; Martsinovsky/Marzinowsky.

${ }^{2}$ The USSR was subsequently excluded from the League of Nations in 1939.

${ }^{3}$ English version by the Israel Program for Scientific Translations: Peter P. Perfil'ev, Diptera: sand flies (Family Phlebotomidae). Fauna of the USSR, v.3, n.2. 1966.

\section{REFERENCES}

ADLER, Saul.

The transmission of Leishmania tropica by the bite of Phlebotomus papatasi. Indian Journal of Medical Research, v.29, p.803-809. 1941.
ALAM, Mohammad et al.

Identification of the agent causing visceral leishmaniasis in Uzbeki and Tajiki foci by analysing parasite DNA extracted from patients' 
Giemsa-stained tissue preparations. Parasitology, v.136, n.9, p.981-986. 2009.

AL-JAWABREH, Amer et al.

Identification of geographically distributed subpopulations of Leishmania (Leishmania) major by microsatellite analysis. BMC Evolutionary Biology, v.8, n.183. 2008 .

\section{ARTEMIEV, Mikhail M.}

A revision of sand flies of the subgenus Adlerius.

Zoology Journal, v.8, p.1177-1193. [in Russian]. 1980.

ARTEMIEV, Mikhail M.

Sand flies (Diptera, Psychodidae, Phlebotominae) of Afghanistan. Kabul: Ministry of Health/Malaria and Leishmania Institute; Kabul Press. 1978.

ARTEMIEV, Mikhail M.; NERONOV, Valery M. Distribution and ecology of sand flies of the Old World (genus Phlebotomus). Moscow: Institute of Evolution, Morphology and Animal Ecology; The USSR Committee for the UNESCO Programme on Man and Biosphere Press. [in Russian]. 1984.

BAGIROV, Ghazi A. et al.

Resistence of imago and larvae of Anopheles masculipennis sacharovi to DDT in Azerbaijan. In: Lysenko, Andrey Ya. (Ed.). Modern problems of malaria prevention in the USSR. Baku: Research Institute of Medical Parasitology and Tropical Medicine named after S.M. Kirov Press. p.157162. [in Russian]. 1973.

BARANOVA, Alla M.

Activities of the WHO collaborative centre for study of vivax malaria. Meditsinskaia parasitologiia i parazytarnye bolezni, v.4, p.15-18. [in Russian]. 2010.

BARANOVA, Alla M. et al.

Malaria. In: Pokrovsky, Valentin I.; Onishenko, Gennady G.; Cherkassky, Veniamin L. (Ed.). The evolution of infectious diseases in Russia in the $X X$ century. Moscow: Medicine Press. p.412-432. [in Russian]. 2003.

BARDZHADZE, Bejan G.

Treatment of visceral leishmaniasis.

Meditsinskaia parasitologiia i parasitarnye bolezni, v.6, p.11-16. [in Russian]. 1979.

BEKLEMISHEV, Vladimir N.

Ecology of the malaria mosquito. Moscow:

Commissariat of Health Press. [in Russian]. 1944a.

BEKLEMISHEV, Vladimir N.

Principles of comparative anatomy of invertebrates. Moscow: Sovietskaya Nauka Press. [in Russian]. 1944b.

BELJAEV, Andrey E. et al.

Plasmodium vivax: further observation on polymorphism in relation to the duration of exoerythrocytic development. In: Beyer, Tatyana V. et al. (Ed.). Malarial parasites of mammals. Protozoology Series. Leningrad: Nauka Press, p.140-157. [in Russian]. 1986.

BERG, Henk van den.

Global status of DDT and its alternatives for use in vector control to prevent disease. Environmental Health Perspectives, v.117, n.11, p.1656-1663. 2009.

BETTMANN, Siegfried; WASIELEWSKI, Theodor von.

Zur Kenntnis der Orientbeule und ihres

Erregers. Archiv für Schiffs- und Tropenhygiene, v.13, n.5. 1909 .

BOROVSKY, Peter F.

About Sartovsky ulcers. Military Medical Journal, v.195, n.11, p.25-41. 1898.

BRAY, Robert S.

Leishmaniasis in the Old World. British Medical Bulletin, v.28, n.1, p.39-43. 1972.

BRAY, Robert S. et al.

The parasite causing cutaneous leishmaniasis in Ethiopia. Transactions of the Royal Society of Tropical Medicine and Hygiene, v.67, n.3, p.345348. 1973.

BRUCE-CHWATT, Leonard Jan.

Malaria research and eradication in the USSR: a review of Soviet achievements in the field of malariology. Bulletin of the World Health Organization, v.21, p.737-772. 1959.

CUNNINGHAM, David Douglas.

On the presence of peculiar parasitic organisms in the tissue of a specimen of Delhi. Scientific Memoirs by Medical Officers of the Army of India, v.1, p.21-31. 1885.

DANILOV, Valery N. et al.

New mosquito species, Aedes (Ochlerotatus) sergievi sp. n. Parazitologiia, v.12, n.1, p.44-49. [in Russian]. 1978.

DERGACHEVA, Tatyana I.

About the question of the fauna and ecology of sand flies (Phlebotomidae) in Agdam region of Azerbaijan SSR. In: Lysenko, A. Ya (Ed.). Proceeding of the Research Institute of Medical Parasitology and Tropical Medicine. Baku: Research Institute of Medical Parasitology and Tropical Medicine named after S.M. Kirov Press. p.156164. [in Russian]. 1969.

DERGACHEVA, Tatyana I.; STRELKOVA, Margarita V.

Epidemiological role of sandflies Phlebotomus smirnovi Perfiliev, 1941 and P. longiductus Parrot, 1928 in visceral leishmaniasis foci in the Kazakh SSR. Transactions of the Royal Society of Tropical Medicine and Hygiene, v.79, n.1, p.34-36. 1985. 
DERGACHEVA, Tatyana I. et al.

Diurnal activity of Phlebotomus smirnovi, Perf. 1941 and its attack on man under the natural conditions of Kzyl-Orda Province, the Kazakh SSR. Meditsinskaia Parazitologiia i Parazitarnye bolezni, v.5, p.75-81. [in Russian]. 1978.

DETINOVA, Tatyana S.

Age-grouping methods in Diptera of medical importance with special reference to some vectors of malaria. Monograph series World Health Organization, v.47, p.13-191. 1962.

DOLMATOVA, Anna V.; DEMINA, Nadezhda A. Sand flies and diseases transmitted by them. Moscow: Medicine Press. [in Russian]. 1965.

DONOVAN, Charles.

On the possibility of the occurrence of trypanosomiasis in India. British Medical Journal, v.2, p.79. 1903.

ELFARI, Mohammed et al.

Genetic and biological diversity among populations of Leishmania major from Central Asia, the Middle East and Africa. Microbes and Infection, v.7, n.1, p.93-103. 2005.

ELISEEV, Lev N.

Strategy of the control with great gerbils in epidemically dangerous regions of zoonotic leishmaniasis. In: Kucheruk Valent V. (Ed.). Ecology and medical value of great gerbils in the fauna of the USSR. Alma-Ata; Moscow: Medicine Press. p.326-331. [in Russian]. 1981.

ELISEEV, Lev N.

Basic principles of organizing and conducting of zoonotic cutaneous leishmaniasis control in the Karshin steppe, Uzbek SSR. Moscow: WHO Traveling Seminar on Leishmaniasis Control. 1980.

ELISEEV, Lev N.; STRELKOVA, Margarita V. Evaluation of the capacity of sand flies (Phlebotomidae) for transmission of Leishmania tropica major among large gerbils (Rhombomys opimus). Meditsinskaia Parazitologiia $i$ Parazitarnye Bolezni, v.3, p.284-293. [in Russian]. 1970.

FEDOROVA, Olga V.; KHOMCHENOVSKY, Evgeny I.

Determination of the optimal method for treatment of experimental malaria using Artemisinin. Meditsinskaia Parazitologiia i Parasitarnye Bolezni. v.6, p.8-13. [in Russian]. 1988a.

FEDOROVA, Olga V.; KHOMCHENOVSKY, Evgeny I.

The study of antimalaria action of national Artemisinin in shizant Plasmodium berghei infection in mice. Meditsinskaia Parasitologiia $i$ Parazitarnye Bolezni, v.5, p.11-15. [in Russian]. 1988b.

GARNHAM, Percy Cyril Claude et al.

A strain of Plasmodium vivax characterized by prolonged incubation: morphological and biological characteristics. Bulletin of the World Health Organization, v.52, n.1, p.21-32. 1975.

GAUSE, Georgy F.; BRAZHNIKOVA, Maria G. Gramicidin $S$ and its use in the treatment of infected wounds. Nature, v.154, n.3918, p.703. 1944.

GAVRON, Daniel.

Saul Adler: pioneer of tropical medicine. Rehovot: Balaban Publishers. 1997.

GIBSON, Mary E.

The identification of kala-azar and the discovery of Leishmania donovani. Medical History, v.27, p.203-213. 1983.

GREENBLATT, Charles L.

The present and future of vaccination for cutaneous leishmaniasis. Progress Clinical and Biological Research, v.47, p.259-285. 1980.

GUNDERS, Arnon E. et al.

Follow-up study of a vaccination programme against cutaneous leishmaniasis. I. Vaccination with a 5 year-old human strain of $L$. tropica from the Negev. Transactions of the Royal Society of Tropical Medicine and Hygiene, v.66, n.2, p.235-238. 1972.

HANDMAN, Emanuela.

Leishmaniasis: current status of vaccine development. Clinical Microbiology Reviews, v.14, n.2, p.229-243. 2001.

HOARE, Cecil Arthur.

Early discoveries concerning the parasite of Oriental Sore (with an English translation of the memoir by P.F. Borovsky: "On Sart sore" 1898). Transactions of the Royal Society of Tropical Medicine and Hygiene, v.32, p.66-92. 1938.

IOFFE-USPENSKY, Inna; USPENSKY, Igor. Beklemishev, Vladimir Nikolayevich. In: Capinera, John L. (Ed.). Encyclopedia of entomology. New York: Springer Science. v.1, p.464-466. 2008.

KELLINA, Olga I.

Problems and current lines in investigations on the epidemiology of leishmaniasis and its control in the USSR. Bulletin de la Société Pathologie Exotique, v.74, p.306-318. 1981.

KELLINA, Olga I.

Principles for the study of Leishmania strains. Moscow: WHO Travelling Seminar on Leishmaniasis Control/USSR Ministry of Health Press. [in Russian]. 1980. 
KELLINA, Olga I.

Methods of cutaneous leishmaniasis control in the USSR. Moscow: WHO Inter-regional Travelling Seminar on Natural Foci of Zoonotic Leishmaniasis; Moscow Press. [in Russian]. 1974.

KELLINA, Olga I.

Investigations of immunity in cutaneous leishmaniasis. 1. Comparison of the immunization with Leishmania tropica major strains of different virulence. Meditsinskaia Parazitologiia i Parazitarnye Bolezni, v.4, p.455462, [in Russian]. 1965.

KELLINA, Olga I.

Tests of the chemotherapeutic activity of monomycin in experimental cutaneous leishmaniasis in white mice. Meditsinskaia Parazitologiia i Parazitarnye Bolezni, n.5, p.572576. [in Russian]. 1963.

KHAMESIPOUR, Ali et al.

Leishmaniasis vaccine candidates for development: a global overview. The Indian Journal of Medical Research, v.123, n.3, p.423-438. 2006.

KHAMESIPOUR, Ali et al.

Leishmanization: use of an old method for evaluation of candidate vaccines against leishmaniasis. Vaccine, v.23, n.28, p.3642-3648. 2005.

KILLICK-KENDRICK, Robert.

Oriental sore: an ancient tropical disease and hazard for European travellers. Wellcome History. v.43, p.4-5. 2010.

KNOPOV, Michail; TARANUKHA, Vasiliy K. Petr Grigoryevich Sergiev (on the occasion of the 120th anniversary of his birth). Meditsinskaia Parazitologiia i Parazitarnye Bolezni, v.2, p.58-61. [in Russian]. 2013.

KORNETOV, Nikolay.

Treatment of visceral leishmaniasis by solusurmine. Meditsinskaia Parazitologiia $i$ Parazitarnye Bolezni, v.6, p.88-92. [in Russian]. 1942.

KOVALENKO, Dmitry A. et al.

Canine leishmaniasis and its relationship to human visceral leishmaniasis in Eastern Uzbekistan. Parasites and Vectors, v.4, n.58. 2011.

KUZNETSOV, Robert L.

Contribution of P.G. Sergiev, Sh.D. Moshkovsky, V.N. Beklemishev to the theory and practice of malaria control in the world. Meditsinskaia Parasitologiia i Parasitarnye Bolezni, v.5, p.11-14. [in Russian]. 1990.

LAVERAN, Charles Louis Alphonse. Leishmanioses: kala-azar, bouton d'Orient, leishmaniose américaine. Paris: Masson Press. 1917.
LAVERAN, Charles Louis Alphonse.

Note on Leishman-Donovan bodies. Bulletin de l'Académie Nationale de Médecine, v.50, p.238240. 1903.

LEISHMAN, William Boog.

On the possibility of the occurrence of trypanosomiasis in India. British Medical Journal, v.1, p.1252-1254. 1903.

\section{LITVINOV, Sergey K.}

Experience of international cooperation of the Martsinovsky Institute of Medical Parasitology and Tropical Medicine. Meditsinskaia Parazitologiia i Parazitarnye Bolezni, v.4, p.10-15. 2010.

LÜHE, Max.

Die im Blute schmarotzenden Protozoen und ihre nächsten Verwandten. In: Mense, Carl Anton (Ed.). Handbuch der Tropenkrankheiten. v.3. Leipzig: J.A. Barth. p.69-268. 1906.

LYSENKO, Andrey Ya; BELJAEV, Andrey E. Quantitative approaches to epidemiology. In: Peters, William; Killick-Kendrick, Robert (Ed.). The leishmaniases in biology and medicine. v.1. London: Academic Press. p.263-290. 1987.

LYSENKO, Andrey Ya. et al. Population studies of Plasmodium vivax. 1. The theory of polymorphism of sporozoites and epidemiological phenomena of tertian malaria. Bulletin of the World Health Organization, v.55, n.5, p.541-549. 1977.

MARTSINOVSKY, Evgeny I. Autobiography of Professor Martsinovsky. Medical Parasitology and Parasitic Diseases, v.1, p.7-15. [in Russian]. 1935.

MARTSINOVSKY, Evgeny I.

Phlebotomus caucasicus, sp. n. Medical Revue, n.87, p.611-614. [in Russian]. 1917.

MARTSINOVSKY, Evgeny I.

Maladies voisines de la malaria en Russie: kalaazar, fièvre de Malte, etc. Bulletin de la Société de Pathologie Exotique, v.5, n.10, p.868-876. 1912.

MARTSINOVSKY, Evgeny I. Aetiology of Oriental sore (bouton d'Orient) and brief information about the disease. Thesis (Doctor of Medicine) - Medical Faculty of the Imperial Moscow University, Moscow. [in Russian]. 1909.

MARTSINOVSKY, Evgeny I.; SHURENKOVA, Alexandra I.

Oriental sore (bouton d'Oriental) and immunity in this disease. Russian Journal of Tropical Medicine, v.2, p.2-24. [in Russian]. 1924.

MARZINOWSKY, Evgeny I. Oriental sore (bouton d'Orient) and its treatment. Medizinskoje Obozrenije, v.19, p.732. [in Russian]. 1912. 
MARZINOWSKY, Evgeny I.

Cultures de Leishmania tropica parasite du bouton d'Orient. Bulletin de la Société de Pathologie Exotique, v.2, n.10, p.591-598. 1909.

MARZINOWSKY, Evgeny I.; BOGROW, Sergey L. The aetiology of oriental sore. Medizinskoje Obozrenije, v.61, p.207. [in Russian]. 1904a.

MARZINOWSKY, Evgeny I.; BOGROV, Sergey L. Zur Ätiologie der Orientbeule (bouton d'Orient). Virchows Archiv für pathologische Anatomie und Physiologie und für klinische Medizin, v.178, n.1, p.112-123. 1904b.

MESNIL, Felix.

Review of: Wright, J.H. (1903)-(q.v.). Bulletin de l'Institut Pasteur, n.2, p.114. 1904.

MIRZOYAN, Nikolay A.

Treatment of visceral leishmaniasis by short course of solusurmine. Meditsinskaia Parazitologia i Parazitarnye Bolezni, v.6, p.503508. [in Russian]. 1958.

MODABBER, Farouk.

Vaccines against leishmaniasis. Annals of Medicine and Tropical Parasitology, v.89, supl.1, p.83-88. 1995.

MOSHKOVSKY, Shabsay D.

The attempt to explain the difference in duration of incubation and associated features of acute manifestation of malaria caused by different strains of Plasmodium vivax. Meditsinskaia Parazitologiia i Parazitarnye Bolezni, v.4, p.393-400. [in Russian]. 1973.

MOSHKOVSKY, Shabsay D.

The main regularities of the epidemiology of malaria. Moscow: Academy of Medical Science of the USSR Press. [in Russian]. 1950.

NAGGAN, Lechaim et al.

Follow-up study of a vaccination programme against cutaneous leishmaniasis. II. Vaccination with a recently isolated strain of $L$. tropica from Jericho. Transactions of the Royal Society of Tropical Medicine and Hygiene, v.66, n.2, p.239-243. 1972

NEILL, Deborah J.

Networks in tropical medicine: internationalism, colonialism, and the rise of a medical specialty, 1890-1930. Stanford: Stanford University Press. 2012.

PALATNIK-DE-SOUSA, Clarisa B.

Vaccines for leishmaniasis in the fore coming 25 years. Vaccine, v.26, n.14, p.1709-1724. 2008.

PAWLOWSKY, Evgeny N.

Zur Entdeckungsgeschichte der Leishmaniaparasiten. Zentralblatt für Bakteriologie, Mikrobiologie und Hygiene, n.128. 1931.
PAWLOWSKY, Evgeny N.

On the history of the discovery of the parasites of Pendeh sore. Pensée Médicale Uzbéquistane, n.2. [in Russian]. 1927.

PERFIL'EV, Peter P.

Diptera. Moskity (Semejstvo Phlebotomidae). Fauna SSSR, Leningrad: Nauka Press. v.3, n.2. [in Russian]. 1966.

\section{PETERSEN, Oskar W.}

Die Salvarsanbehandlung der Orientbeule (Leishmaniose). Münchener Medizinische Wochenschrift, v.59, p.2491. 1912.

PONIROVSKY, Evgeny N. et al.

The epidemiological situation of leishmaniasis in the Russian Federation: the first valid cases of local transmission. Meditsinskaia Parazitologiia i Parazitarnye Bolezni, v.3, p.3-7. [in Russian]. 2015.

RABINOVICH, Susanna A. et al.

Monitoring delagil (chloroquine) efficacy against imported Plasmodium vivax strains. Meditsinskaia Parazitologiia i Parazitarnye Bolezni, v.4, p.46-48. [in Russian]. 2010.

RASHINA, Maria G.

E.I. Martsinovsky, organizer of control of malaria in USSR. Meditsinskaia Parazitologiia i Parazitarnye Bolezni, v.4, p.362-368. [in Russian]. 1954.

ROSS, Ronald.

Further notes of Leishman's bodies. British Medical Journal, v.2, p.1401. 1903a.

ROSS, Ronald.

Note on the bodies recently described by

Leishman and Donovan. British Medical Journal, v.2, p.1261-1262. 1903b.

RUSSELL, Alexander. Mal of Aleppo. In: Russel, Alexander. The natural history of Aleppo and parts adjacent. London: A. Millar. 1756.

SAF'JANOVA, Vera M.

Phlebotominae sandflies as the key link of Leishmania parasitic systems. Parassitologia, v.33, supl., p.505-511. 1991.

SAF'JANOVA, Vera M.

The problems of the classification and phylogeny of the Leishmania. In: Rioux, Jean-Antoine (Ed.). Leishmania, taxonomie et phylogenèse: application éco-epidemiologiques. Montpellier: IMEE. p.247-255. 1986.

SAF'JANOVA, Vera M.

The problem of taxonomy of Leishmania. In: Beyer, Tatyana; Kellina, Olga; Saf'janova, Vera (Ed.). Leishmania. Protozoology Series. Leningrad: Nauka Press. p.5-109. [in Russian]. 1982. 
SAF'JANOVA, Vera M.; ALIEV, Eldar I. Comparative study of biological characteristics of the causal agents of zoonotic and anthroponotic cutaneous leishmaniasis in the USSR. Bulletin of the World Health Organization, v.49, n.5, p.499-506. 1973.

SCHULGIN, Konstantin Ya.

The question of the aetiology of Penjdeh sore. Russky Wratsch, v.32, n.33, p.1150-1180. [in Russian]. 1902.

SERGENT, Edmont et al.

Transmission du clou de Biskra par le phlébotome (Phlebotomus papatasi Scop.). Comptes Rendus Hebdomadaires des Séances de l'Académie des Sciences, v.173, p.1030-1032. 1921.

SERGIEV, Peter G.

The achievements of soviet medical science in the control of malaria. Moscow: Foreign Languages Publishing House. 1955.

SERGIEV, Peter G.; TIBURSKAYA, Nadezhda A. Independent coexistence of Plasmodium vivax strains with long and short incubation. Meditsinskaia Parazitologiia i Parazitarnye Bolezni, v.5, p.576-579. [in Russian]. 1963.

SERGIEV, Peter G. et al.

Results of massive vaccination against zoonotic cutaneous leishmaniasis. Meditsinskaia Parazitologiia i Parazitarnye Bolezni, v.5, p.541551. [in Russian]. 1970.

SERGIEV, Peter G. et al.

Malaria eradication in the USSR and particularities of the pass away. Bulletin of the Academy of Medical Science of the USSR, v.4, p.1928. [in Russian]. 1961.

SERGIEV, Vladimir P. et al.

Malaria in the European Region of the World Health Organization, 1970-2000. Copenhagen: WHO Regional Office for Europe. p.73-128. 2007.

SHIPITSINA, Nina K.

Transmission season and zones of malaria in the Soviet Union. In: Moshkovsky, Shabsay D. (Ed.). Problems of medical parasitology and prevention of infectious diseases. Moscow: Ministry of Health of the USSR Press. p.258-276. [in Russian]. 1964.

SOKOLOV, Evgeny I.

The contribution of E.I. Martsinovskii in the prevention of infectious diseases in the USSR. Soviet Medicine, v.23, p.141-146. [in Russian]. 1959.

SOPRUNOV, Fyodor F.

Problems of tropical parasitology and analysis of special programs of scientific research and training of specialists in tropical diseases. Meditsinskaia Parazitologiia i Parazitarnye Bolezni, v.4, p.3-14. [in Russian]. 1981.
SOPRUNOV, Fyodor F.; GOLD, Evgeny Y. P.G. Sergiev. Moscow: Medicine Press. [in Russian]. 1986.

STEGNII, Vladimir N.; KABANOVA, Valentina M. Cytoecological study of natural populations of malaria mosquitoes on the USSR territory. 1. Isolation of a new species of Anopheles in Maculipennis complex by the cytodiagnostic method. Meditsinskaia Parazitologiia i Parazitarnye Bolezni, v.2, p.192-198. [in Russian]. 1976.

STEVERDING, Dietmar.

The history of leishmaniasis. Parasites and Vectors, v.10, n.82, p.1-11. 2017.

STRELKOVA, Margarita V. Progress in studies on Central Asian foci of zoonotic cutaneous leishmaniasis: a review. Folia Parasitologica, v.43, n.1, p.1-6. 1996.

STRELKOVA, Margarita V.; ELISEEV, Lev N. Rodents and reptiles as prey of sand flies (due to their importance in the epizootology of zoonotic cutaneous leishmaniasis). In: Kucheruk, Volodymyr V. (Ed.). Fauna and ecology of rodents. v.15. Moscow: Moscow State University Press. p.55-82. [in Russian]. 1983.

STRELKOVA, Margarita V. et al. A narrative review of visceral leishmaniasis in Armenia, Azerbaijan, Georgia, Kazakhstan, Kyrgyzstan, Tajikistan, Turkmenistan, Uzbekistan, the Crimean Peninsula and Southern Russia. Parasites and Vectors, v.8, p.330. 2015.

STRELKOVA, Margarita V. et al. Comparison of virulence of Leishmania major strains from Uzbekistan and Israel. Problems of Biology and Medicine, v.1, n.33, p.77-78. 2004.

STRELKOVA, Margarita V. et al.

Ecology and the genetic structure of sympatric Leishmania species circulating in the intracontinental deserts of the south Palaearctic region. Meditsinskaia Parazitologiia i Parazitarnye Bolezni, v.3, p.12-18. [in Russian]. 2003.

STRELKOVA, Margarita V. et al.

Mixed leishmanial infections in Rhombomys opimus: a key to the persistence of Leishmania major from one transmission season to the next. Annals of Tropical Medicine and Parasitology, v.95, n.8, p.811-819. 2001.

STRELKOVA, Margarita V. et al. A new species of Leishmania isolated from the great gerbil Rhombomys opimus. Parasitology, v.101, n.3, p.327-335. 1990.

STRELKOVA, Margarita V. et al.

Experimental transmission of the causative agent of visceral leishmaniasis, Leishmania donovani, to golden hamsters by Phlebotomus 
longiductus, Parr. 1928 and Phlebotomus smirnovi, Perf. 1941 sandflies. Meditsinskaia Parazitologiia i Parazitarnye Bolezni, v.3, p.49-54. [in Russian]. 1982.

SUKIASYAN, Anna et al. Re-emerging foci of visceral leishmaniasis in Armenia: first molecular diagnosis of clinical samples. Parasitology, v.146, n.7, p.1-8. 2019.

\section{TSCHEREPNIN.}

Die Hautkrankheit der Sarten, (Păschă-Chùrdj). St. Petersburger Medizinische Wochenschrift, v.2, p.1-3. 1876.

WHO.

World Health Organization. Report of a training seminar on epidemiological methods for the leishmaniases. Moscow, Baku, Samarkand, 28 May-19 June 1980. Geneva: WHO. 1980.

WRIGHT, James H.

Protozoa in a case of tropical ulcer ("Aleppo boil"). Journal of Cutaneous Diseases Including Syphilis, v.22, n.1, p.1-9. 1904.
WRIGHT, James H.

Protozoa in a case of tropical ulcer ("Delhi Sore"). Journal of Medical Research, v.10, p.472482. 1903.

YAKIMOFF, Wassily L.

Contribution à l'étude des leishmanioses de l'homme et du chien dans le Turkestan Russe. Bulletin de la Société de Pathologie Exotique, v.8. 1915a.

YAKIMOFF, Wassily L.

Proceedings of the expedition to study tropical diseases of humans and animals in Turkestan in 1913. v.1: Leishmaniasis. Petrograd: Y.A. Trey. Russia. [in Russian]. 1915b.

YAKIMOFF, Wassily L.; SCHOKHOR, Natan I. Recherches sur les maladies tropicales humaines et animales au Turkestan. II. La leishmaniose cutanée (bouton d'Orient) spontanée du chien Turkestan. Bulletin de la Société de Pathologie Exotique, v.7, p.186-187. 1914. 